|Araştırma Makalesi / Research Article|

\title{
Görsel Sanatlar Eğitiminde Edebiyat Ürünlerinin Öğrenci Çalışmalarına Etkisi
}

\section{The Effect of Literature Works on Pupils Studies at Visual Arts Education}

\section{Muhammet İnceağaç ${ }^{1}$, Meliha Yılmaz ${ }^{2}$}

\author{
Anahtar Kelimeler \\ görsel sanatlar eğitimi \\ disiplinlerarası sanat \\ eğitimi \\ görsel sanatlar \\ eğitiminde edebiyat \\ ürünlerinin kullanımı
}

\section{Keywords}

visual arts education

interdisciplinary art

education

use of literature

products in visual arts

education

\section{Başvuru Tarihi/Received}

27.02.2020

Kabul Tarihi /Accepted

10.04.2020

\section{Öz}

Bu araştırma, ortaokul öğrencilerinin görsel sanat çalışmalarına edebiyat ürünlerinin etkisi olup olmadığını, etkisi var ise hang düzeyde olduğunu belirlemek amacıyla yapılmıştır. Araştırma 2016-2017 eğitim öğretim yılında Kastamonu ilinde bulunan dört ortaokulun 6. sınıfında öğrenim gören öğrencileri ile sınırlıdır. Araştırma öntest ve sontest olmak üzere çalışmanın tamamına katılan ve çalışmalarını (resimlerini) tamamlamış olan 50 öğrenciyi kapsamaktadır. Araştırmanın uygulama konusu edebiyat ürünlerinden olan fabl, atasözü-deyim ve efsane türleri ile sınırlandırılmıştır. Öğrenci resimleri, kuru boya tekniği ile gerçekleştirilmiştir. Araştırmada, nicel araştırma yöntemlerinden deneysel bir tür olan, tek denekli araştırma modeli içinde yer alan tek gruplu öntest-sontest model kullanılmıştır. Ayrıca öğrenci çalışmaları nitel araştırma kapsamında betimlenerek yorumlanmıştır. Araştırmanın veri toplama araçları öğrencilerin yapmış olduğu serbest çalışmaya ait resimler (öntest) ve edebiyat ürünlerinin kullanımına yönelik resimlere (sontest) dayanmaktadır. Öğrenci çalışmaları; görsel sanatlar eğitimi uygulamalarında edebiyat ürünlerinin etkisini belirlemek amacıyla geliştirilmiş ve yayınlanmış olan dereceli puanlama anahtarı (rubrik) kullanılarak, üç alan uzmanı tarafından değerlendirilmiştir. Veri toplama araçlarından elde edilen veriler, bilgisayar ortamına geçirilmiş ve 'SPSS' analiz programı kullanılarak analiz edilmiştir. Görsel sanatlar eğitimi uygulamalarında edebiyat ürünlerinin etkisini belirlemeye yönelik dereceli puanlama anahtarı içerisindeki kriterlere dayalı öntest ve sontest puanlarının karşılaştırılması, Wilcoxon işaretli sıralar testi ile incelenmiştir. Araştırmadan elde edilen verilere göre; nicel araştırma yöntemlerinden deneysel bir tür olan, tek denekli araştırma modeli içinde yer alan tek gruplu öntest-sontest test puanları arasında bütünlük ve görsel devamlıık, hareket ifadesi, imge zenginliği, renk kullanımı, ayrıntılara yer verme, mekân ifadesi, kompozisyon, yaratıcı düşünme, stereotip biçim kullanımı kriterleri açısından istatistiksel olarak sontest lehine anlamlı bir fark ortaya çıkmıştır.

\section{Abstract}

This research has been made to determine whether there is on effect of literature works (genres) on visual arts studies of secondary school students; if there is, it is aimed at detecting the level of this effect. The research is limited with the pupils, studying at 6 . grade of four secondary school in Kastamonu in 2016-2017 educational year. The research covers 50 students who has joined the whole study as pretest and posttest and who has completed their studies (pictures). The application subject of the research is limited with some literature genres such as fable, proverbs-idioms and myths. Dry paints technique has been used in students' pictures. At the research, one grup pretest-posttest model is used; that is one of the experimental kinds of quantitative research methods and involved in single subject research models. In addition, student studies were described and interpreted in the context of qualitative research. The data acquisition tools of the research depends on the pictures made by the students on free style (pretest) and the pictures about the useage of literary works (posttest). Students works have been evaluated by three branch experts using guide scoring key (rubric) which has been developed and published for determining the effects of literary genres over the visual arts education practises. The data obtained through data acquisition tools have been computerised and evalvated by "SPSS" analysis programme. The comparison of pretest and posttest results depending on the criterias in the rubric for determining the effects of literary genres over visual arts education practises is analysed by using Wilcoxon signed rank test. According to the data which is obtained by the research a statistically significant difference is found out between the test points of one group pretest-posttest model which is one of the experimental kinds of quantitative research methods and involved in single subject research models in terms of those measures as unity, visual continuity, state of motion, plentity of image, colour usage, content of details, state of location, composition, creative thinking and usage of stereotype forms.

Bu araştırma, birinci yazarın ikinci yazar danışmanlığında hazırladığı ‘Görsel Sanatlar Eğitiminde Edebiyat Ürünlerinin Öğrenci Çalışmalarına Etkisi’ başlıklı doktora tezinden üretilmiştir.

${ }^{1}$ Sorumlu Yazar, Kastamonu Üniversitesi, Kastamonu Meslek Yüksekokulu, Grafik Tasarım Bölümü, Kastamonu, TÜRKiYE; https://orcid.org/0000-0001-6175-367X ${ }^{2}$ Gazi Üniversitesi, Gazi Eğitim Fakültesi, Güzel Sanatlar Eğitimi Bölümü Resim-İ̧ Eğitimi Ana Bilim Dalı, Ankara, TÜRKiYE; https://orcid.org/0000-0002-7732-2660 


\section{Extended Abstract}

This research has been generated from the PhD dissertation titled 'The Effect of Literarture Works on Pupils Studies at Visual Arts Education' which is prepared by a first writer on consultancy of a second writer.

\section{Introduction}

The aim of the research is to reveal whether literary genres have an impact on 6th grade students' visual arts studies or not. Within this purpose, the effect of the literary genres to the students' visual art studies 'in terms of integrity and visual continuity, expression of motion, image use (image variety and richness), color use (color richness), details (detail), space expression, composition, creative thinking (original expression) and stereotype form usage criteria' effect has been investigated.

\section{Method}

As a pretest practise of the research, students were asked to draw a subject they wish without any subject limitation. In the posttest 1 practise of the study three fables, in the posttest 2 practise fifteen proverbs and fifteen idioms, in the posttest 3 practise two legend examples were used. In the posttest 1 practise, the selected examples of fables were explained and then the students were asked to paint their own chosen fables. In the posttest 2 practise, the selected proverb and idiom examples were written on the board and then the students were asked to select and paint one of the proverb or idiom examples. In the posttest 3 practise, selected legend examples were explained and then students were asked to write and paint a legend they composed.

In the research, one-group pretest-posttest design, which is an experimental type of quantitative research methods, is included in the singlesubject research model. According to Baştürk (2011), one group pretest-posttest design information of a single group in the research is measured before practising (pretest), then the practise is carried out after practising, the measurement is reapplied to the same group (posttest). If the obtained data show a statistically significant difference between the pretest and posttest results $\left(\mathrm{O}_{1,2}>\mathrm{O}_{1,1}\right)$, this difference is considered to be caused by the practise $(X)(p .37)$.

Research was held in four schools in the city center of Kastamonu, selected by random method, in the same equivalent, Vali Aydın Arslan Secondary School, Şerife Bacı Secondary School, Fatih Sultan Mehmet Secondary School and Kuzeykent Secondary School at the second term of 2016-2017 academic year. Students who are not at any stage of the 4-class experimental study applied to 6th grade students are not evaluated. There were totally 50 students who were participating in all stages of the study and delivering their work in full. The first week of the research process is devoted to pretesting, the second week to posttest 1 , the third week to posttest 2 , and the fourth week to posttest 3 . Student studies were collected at the end of each practise. In the scoring of the research, a five-point Likert-type grading key (rubric) developed and published by Yılmaz and İnceağaç (2017) in Chart 2 was used as a data collection tool. Student studies were scored based on rubric criteria by three specialist academics. Comparison of the pre-test and post-test scores of the graded scoring key used in the study was carried out with the Wilcoxon signed rank test. Significance level was based on as $p<0.05$.

This test, also known as Wilcoxon paired test; It is used to test the significance of the difference between the scores of the two related measurement sets. This technique is often used in intergroup studies with few subjects in social sciences. In conditions where the difference scores of the subjects do not show a normal distribution, it is used instead of the related sample t-test. Here, the scores obtained from measurements made at two different times on two paired groups or on the same subjects are subjected to analysis (Büyüköztürk, 2012, pp.162163). Also, the general pretest and posttest studies were interpreted descriptively. Student studies are shown in Appendix 1.

\section{Result and Discussion}

As a result of using literary genres; It is shown that Table 3 is considered as integrity and visual continuity $(Z=6,18, p<0,05)$, Table 4 motion expression $(Z=6,09, p<0,05)$, Table 5 image usage $(Z=6,18, p<0,05)$, Table 6 color usage $(Z=6,18, p<0,05)$, Table 7 details $(Z=6,16, p<0,05)$, Table 8 space expression $(Z=5,88, p<0,05)$, Table 9 composition $(Z=6,18, p<0,05)$, Table 10 creative thinking $(Z=6,14, p<0,05)$ and Table 11 usage of stereotype form $(Z=5,94, p<0,05)$. It is seen that there is a significant difference between the pretest and posttest scores of all criteria. Considering the rank average and total of the difference scores in terms of each criterion, it is seen that this observed difference is in favor of positive ranks, that is, the posttest score.

As a result of using literary genres in student practises in visual arts education course; a significant difference has emerged in favor of posttest in terms of integrity and visual continuity, movement expression, image use, use of color, giving details, location expression, composition, creative thinking and stereotype use. In other words, it can be said that literary genres have an important effect in increasing students' success levels in terms of all criteria. This shows that it is important to take advantage of literary genres in visual arts lessons. It is seen that the results of the research and the effect of the literary genres have a positive effect on success on the determined artistic criteria, which are far from imitation (cliche) and copying, have imaginative creative thinking skills.

Based on the results of the research, it should be preferred to make use of the genres of various types of literature frequently in the visual arts lesson. The type of literature to be used should be determined in line with the needs of the students and the points that should be supported for the purposes of the course, and products and works suitable for them should be preferred. Considering that using literary genres in visual arts course will lead to different and effective results, the use of different methods and artistic techniques should be given importance. For example, completing the legend, which is left unfinished, cross-sectional illustration, determining the image, creating your own hero, visualizing the spaces, three-dimensional works from the legend heroes, masks, puppets, etc. artistic techniques and various methods should be used. 


\section{GíRiş}

Günümüz görsel sanatlar öğretim programlarında kazanımlara uygun olmak kaydıyla içeriğin belirlenmesi öğretmenlere bırakılmıştır. Bu anlamda tüm disiplin alanlarından yararlanılabileceği gibi, özellikle edebiyat, görsel sanatlar dersinde yararlanılabilecek ve dersin amaçlarına ulaşmada etkili olabilecek alanlardan birini oluşturmaktadır. Yazılı ve sözlü edebiyat türlerine ait ürünler ve eserler öğrenci seviyesine uygun olmak kaydıyla görsel sanatlar dersine içerik bakımından zengin birer kaynak teşkil edebilirler.

Edebiyat; duygu, düşünce, hayal ve izlenimlerin sözlü veya yazılı olarak güzel ve etkili bir biçimde anlatılma sanatıdır. Başka bir ifadeyle edebiyat, sözcüklerle yapılan bir güzel sanattır, dil sanatıdır. Bu açıdan edebiyat, bütün güzel sanatlar gibi insanlık düşüncesine öncülük etmektedir (Kavcar, 2017, s.108).

Akıldan resim yapmak kendilerinden yapmaları istenen nesne, kişi, hayvan veya çevre hakkında ne hatırladıklarına veya resim yaparken hatırlamayı seçtiklerini yapmalarına dayanır. Akıldan resim yapmak her çocuk için (ve hatta yetişkinler için de) kolay bir şey değildir (Malchiodi, 2005, s.47). Öğrencileri yaratıcı ve çok yönlü düşünmeye, hayalinde canlandırmaya sevk edebilecek nitelikte, edebiyatın çeşitli türlerine ait kaynaklar seçilerek resimlemelerine yardımcı olunabilinir. Bu anlamda, edebiyatın masal, anı, hikaye, destan, efsane, fabl, şiir, atasözü, özdeyiş, deyim, tekerleme vb. pek çok türünden yararlanma yoluna gidilebilir.

Bu araştırmanın amacı, edebiyat ürünlerinin 6. sınıf öğrencilerinin görsel sanat çalışmaları üzerine etkisi olup olmadığını ortaya koymaktır. Bu amaç kapsamında, edebiyat ürünlerinin öğrencilerin görsel sanat çalışmalarına; 'bütünlük ve görsel devamlılı, hareket ifadesi, imge kullanımı (imge çeşitliliği ve zenginliği), renk kullanımı (renk zenginliği), ayrıntılara (detaya) yer verme, mekân ifadesi, kompozisyon, yaratıcı düşünme (özgün ifade) ve stereotip biçim kullanımı’ kriterleri açısından etkisi araştırılmıştır.

Bu amaçla araştırmada, edebiyatın fabl, atasözü-deyim ve efsane türünden yararlanılmıştır. Çalışmada tercih edilen fabllar, atasözleri, deyimler ve efsaneler, öğrencileri imgesel düşünmeye, farklı ve yaratıcı yaklaşımlara, eğlenceli ve keyifli çalışmaya, özgün biçimlendirmelere sevk edeceği düşünülen farklı nitelikte insanlar, çeşitli hayvanlar ve mitolojik figüratif unsurlar, bu figürlere ait farklı hareketler, tasvirler, mekânlar ve anlatılar içermesinden dolayı tercih edilmiştir.

\section{YÖNTEM}

\section{Araştırma Modeli}

Araştırmanın öntest uygulaması olarak öğrencilerden konu sınırlaması olmaksızın diledikleri bir konuda resim yapmaları istenmiştir. Çalışmanın sontest 1 uygulamasında üç fabl, sontest 2 uygulamasında on beş atasözü, on beş deyim ve sontest 3 uygulamasında ise iki efsane örneği kullanılmıştır. Uygulamada kullanılan fabl, atasözü, deyim ve efsane örneklerine ayrıntılı olarak kapsam ve sınırlılıklar başlığında yer verilmiştir. Sontest 1 uygulamasında, seçilen fabl örnekleri anlatılmış daha sonra öğrencilerden kendi seçtikleri fablı resmetmeleri istenmiştir. Sontest 2 uygulamasında, seçilen atasözü ve deyim örnekleri tahtaya yazılarak anlatılmış sonrasında öğrencilerden atasözü veya deyim örneklerinden bir tanesini seçip resmetmeleri istenmiştir. Sontest 3 uygulamasında ise, seçilen efsane örnekleri anlatılmış daha sonra öğrencilerden kendi oluşturdukları bir efsaneyi yazmaları ve resmetmeleri istenmiştir.

Araştırmada, nicel araştırma yöntemlerinden deneysel bir tür olan, tek denekli araştırma modeli içinde yer alan tek gruplu öntest-sontest model kullanılmıştır. Baştürk (2011)'e göre, tek grup öntest- sontest modelde araştırmada yer alan tek bir grubun uygulama öncesi bilgileri ölçülür (öntest), daha sonra uygulama gerçekleştirilir ve uygulama sonrasında tekrar aynı gruba ölçme işlemi uygulanır (sontest). Elde edilen veriler öntest ile sontest sonuçları arasında istatistiksel olarak anlamlı bir fark gösteriyorsa $\left(\mathrm{O}_{1,2}>\mathrm{O}_{1,1}\right)$ bu farkın uygulamadan $(\mathrm{X})$ kaynaklandığı kabul edilmektedir (s.37). Baştürk (2011)'e göre, bu model ile ilgili kodlama Şekil 1'de verilmektedir.

$\begin{array}{cccc}\underline{\text { Grup }} & \underline{\text { Öntest }} & \underline{\text { Uygulama }} & \underline{\text { Sontest }} \\ \mathrm{A} & \mathrm{O}_{1,1} & \mathrm{x} & \mathrm{O}_{1,2} \\ & & & \end{array}$

\section{Zaman}

\section{Şekil 1. Tek grup öntest-sontest model. Kaynak: (Baştürk, 2011, s.37)}

Büyüköztürk, Kılıç Çakmak, Akgün, Karadeniz ve Demirel (2016)'e göre ise bu model, 'tek grup öntest-sontest desen' olarak açıklanır ve bu desene ait simgesel gösterimi 'grup, öntest, işlem, sontest' şeklinde açıklanmıştır (s.201).

\section{Çalışma Grubu}

Araştırma, gönüllülük esasına dayalı olarak çalışmaya katılmayı kabul eden görsel sanatlar öğretmenleri ile gerçekleştirilmiştir. Araştırma 2016-2017 eğitim öğretim yılının II. yarıyılında Kastamonu il merkezinde bulunan, random yöntemiyle seçilen, aynı eşdeğerdeki sırasıyla Vali Aydın Arslan Ortaokulu, Şerife Bacı Ortaokulu, Fatih Sultan Mehmet Ortaokulu ve Kuzeykent Ortaokulu olmak üzere toplam dört okulda yapılmıştır. 6. sınıf öğrencilerine uygulanan 4 derslik deneysel çalışmanın herhangi bir aşamasında 
bulunmayan öğrenciler, değerlendirmeye alınmamıştır. Çalışmanın tüm aşamalarına katılan ve eksiksiz olarak çalışmasını teslim eden toplam 50 öğrenci bulunmaktadır. Araştırmanın çalışma grubunu oluşturan öğrencilerin cinsiyete, okullara ve şubelere göre sayısal dağılımı aşağıda verilmiştir.

Tablo 1. Çalışma grubu

\begin{tabular}{|c|c|c|c|c|c|c|c|c|c|}
\hline & \multicolumn{2}{|c|}{ 1.Okul } & \multicolumn{2}{|c|}{ 2.Okul } & \multicolumn{2}{|c|}{ 3.Okul } & \multicolumn{2}{|c|}{ 4.Okul } & \multirow{2}{*}{ Toplam } \\
\hline & 6/A & $6 / \mathrm{B}$ & 6/A & $6 / \mathrm{B}$ & $6 / A$ & 6/B & $6 / \mathrm{A}$ & $6 / \mathrm{B}$ & \\
\hline Erkek & 3 & 1 & 1 & 1 & 1 & 2 & 1 & 1 & 11 \\
\hline $\mathrm{K} \mathrm{Iz}$ & 5 & 9 & 4 & 4 & 6 & 5 & 3 & 3 & 39 \\
\hline Toplam & 8 & 10 & 5 & 5 & 7 & 7 & 4 & 4 & 50 \\
\hline
\end{tabular}

Buna göre, araştırmanın çalışma grubu, dört farklı okulun 6. sınıfının A ve B şubelerinde öğrenim gören 11 erkek ve 39 kız olmak üzere toplam 50 öğrenciden oluşmaktadır.

\section{Kapsam ve Sınırlılıklar}

Araştırmada, sontest 1 uygulaması için fabl olarak "Ezop (Aisopos) Masalları" (Berrak, \& Hiperlink (Firm), 2007) adlı eserden 'Pınardaki Geyik ile Aslan' adlı fabl, "La Fontaine Masalları” ( (Ed.) Avcıoğlu, \& Hiperlink (Firm), 2010) adlı eserden 'Tilkiyle Horoz' adlı fabl, Beydeba'ya ait "Kelile ve Dimne'den seçmeler" (Yılmaz, 2015) adlı eserden ise 'Kurbağa ve Kazlar' adlı fabl tercih edilmiştir. Beydeba'ya ait fablın orjinali 'Kaplumbağa ve Kazlar' olduğu için eser orjinaline bağlı kalınarak anlatılmıştır.

Bu çalışmanın sontest 2 uygulaması için kullanılan atasözleri, Yılmaz (2014)'a ait 'görsel sanatlar eğitiminde mizahın yeri ve kaynakları' adlı makale çalışmasındaki numaralandırılan atasözleri örnekleriyle sınırlandırılmıştır. '1. Ata nal çakıldığını görmüş kurbağa da ayağını uzatmış. 2. Ağaca çıkan keçinin dala bakan oğlu olur. 3. Anlayana sivrisinek saz, anlamayana davul zurna az. 4. Ağzı büyük olana kepçe kaşık gibi gelir. 5. Bir kere insanın ters gitmesin işi, muhallebi yerken kırılır dişi. 6. Boş boğazı cehenneme atmışlar odunum yaş demiş. 7. Deveye kalk oyna demişler, bir çam bir çardak devirmiş. 8. Gümbürtüden korkan kazancı dükkanına girmez. 9. Her aferine koşan tazının bacağı çabuk kırılır. 10. Karga, kekliği taklit edeyim demiş, kendi yürüyüşünü şaşırmış. 11. Kedinin kanadı olsaydı serçenin kökü kesilirdi. 12. Köpeğe gem vurma, kendini at sanır. 13. Lafla pilav pişse deniz kadar yağ benden. 14. Sütten ağzı yanan, yoğurdu üfleyerek yer. 15. Yazın araması kışın taraması olmasa herkes manda besler'. Bu çalışmanın sontest 2 uygulaması için kullanılan deyimler, numaralandırılan deyim örnekleriyle sınırlandırılmıştır. '1. Ağzına bir parmak bal çalmak. 2. Akıntıya kürek çekmek. 3. Başına devlet kuşu konmak. 4. Bir eli yağda, bir eli balda olmak. 5. Dolap çevirmek. 6 . Eşeğini sağlam kazığa bağlamak. 7. Etekleri zil çalmak. 8. Hık demiş burnundan düşmüş. 9. Karnı zil çalmak. 10. Taşı sıksa suyunu çıkarmak. 11. Turşusunu kurmak. 12. Tüyleri diken diken olmak. 13. Yağmur yağarken küpünü doldurmak. 14. Zihnini kurcalamak. 15. Yerin dibine geçmek'.

Araştırmada, sontest 3 uygulaması için efsane olarak “Andersen'den Masallar, Deniz Kızı ve Prens” (Kamer \& Hiperlink (Firm), 2011) adlı eserden 'Deniz Kızı ve Prens' adlı efsane ile "Zümrüdü Anka (Simurg) Kuşu” (internet, 2017, <https://www.youtube.com/watch?v=bS21rqkmzyY> Erişim Tarihi: 09.03.2017) adlı efsane ile sınırlandırılmıştır. Öntest ve sontest uygulamasına ait çalışmalar, kuru boya tekniği ile sınırlıdır.

\section{Uygulama Süreci}

Araştırmanın uygulama sürecinde, ì Milli Eğitim Müdürlüğü'nden ve Valilik'ten araştırma için gerekli olan izin ve onaylar alınmış, sonrasında ise deneysel çalışma uygulanmıştır. Uygulama, tüm okullarda farklı ders saatlerinde, aynı koşullarda, birer ders saati sürecinde gerçekleştirilmiştir. Araştırma sürecinin, birinci haftası öntest uygulamasına, ikinci haftası sontest 1 uygulamasına, üçüncü haftası sontest 2 uygulamasına ve dördündüncü haftası ise sontest 3 uygulamasına ayrılmıştır. Her uygulamanın sonunda öğrenci çalışmaları toplanmıştır.

\section{Verilerin Toplanması}

Araştırmanın puanlanmasında veri toplama aracı olarak Yılmaz ve İnceağaç (2017) tarafından geliştirilmiş ve yayımlanmış olan beşli likert tipi dereceli puanlama anahtarından (rubrik) yararlanılmıştır. Dereceli puanlama anahtarından 'çalışmanın tamamlanması' kriteri çıkartılmış ve madde ifadeleri revize edilerek kullanılmıştır. Ayrıca ilgili alan yazın incelenerek literatür taranmıştır. Araştırmada kullanılan ölçekte belirtilen kriterlerin kullanımı ile ilgili başarı düzeyi ifadeleri; oldukça zayıf (1), zayıf (2), orta (3), iyi (4), oldukça iyi (5) olarak tanımlanmıştır. Dereceli puanlama anahtarının kriterleri ve bu kriterlere yönelik 1 ile 5 aralığındaki puanlama tablosu aşağıda verilmiştir. 
Tablo 2. Görsel sanatlar eğitimi uygulamalarında edebiyat ürünlerinin etkisini belirlemeye yönelik dereceli puanlama anahtarı (rubrik) tablosu ve puan içerikleri

\begin{tabular}{|c|c|c|c|c|c|c|}
\hline \multirow{3}{*}{ Ölçütler } & \multicolumn{5}{|c|}{ Başarı Düzeyi } & \multirow{3}{*}{ 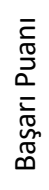 } \\
\hline & $\begin{array}{c}\text { Oldukça } \\
\text { zayıf }\end{array}$ & Zayıf & Orta & İyi & Oldukça iyi & \\
\hline & 1 & 2 & 3 & 4 & 5 & \\
\hline 1. Bütünlük ve görsel devamlılık & 20 & 40 & 60 & 80 & 100 & \\
\hline 2. Hareket ifadesi & 20 & 40 & 60 & 80 & 100 & \\
\hline 3. İmge kullanımı (imge çeşitliliği ve zenginliği) & 20 & 40 & 60 & 80 & 100 & \\
\hline 4. Renk Kullanımı (renk zenginliği) & 20 & 40 & 60 & 80 & 100 & \\
\hline 5. Ayrıntılara (detaya) yer verme & 20 & 40 & 60 & 80 & 100 & \\
\hline 6. Mekân ifadesi & 20 & 40 & 60 & 80 & 100 & \\
\hline 7. Kompozisyon & 20 & 40 & 60 & 80 & 100 & \\
\hline 8. Yaratıcı düşünme (özgün ifade) & 20 & 40 & 60 & 80 & 100 & \\
\hline 9. Stereotip biçim kullanımı & 100 & 80 & 60 & 40 & 20 & \\
\hline
\end{tabular}

Tablo 2'de görüldüğü üzere, 9. madde "stereotip biçim kullanımı" kriterinin puanlanması, ölçeğin diğer maddeleri ile ters orantı göstermektedir. Diğer kriterlerin aksine resimde stereotip biçim kullanımı arttıkça, ürünün başarısı düşmektedir. Yani stereotip biçim kullanımının çokluğu başarıyı düşüren bir durum iken stereotip biçim kullanımı azaldıkça başarı artmaktadır (Yılmaz ve İnceağaç, 2017).

Söz konusu dereceli puanlama anahtarının orijinal halinden bir madde çıkarıldığı için pilot uygulamada toplanan verilere AFA ve DFA uygulanarak, rubriğin yapı geçerliği test edilmiştir. Rubrikte 9. madde olan "stereotip biçim kullanımı" tersten kodlanmıştır. Alan uzmanı üç öğretim üyesinin değerlendirdiği rubrikten elde edilen sonuçların güvenirliği için Kappa ve puanlayıcılar arası korelasyon matrisi incelenmiştir.

Ölçeğin öncelikli olarak, faktör analizine uygun olup olmadığını anlamak amacıyla KMO ve Bartlett testi yapılmıştır. Bu kapsamda KMO testi ölçüm sonucunun 0,60'dan yüksek olması beklenirken, Bartlett küresellik testi sonucunun da istatistiksel olarak anlamlı olması gerekmektedir (Büyüköztürk, 2012). Ölçme aracı için yapılan KMO testi sonucu 0,74'tür. Kaiser, bulunan değerin $1^{\prime}$ 'e yaklaştıkça mükemmel, $0,50^{\prime}$ 'nin altında ise kabul edilemez ( $0,90^{\prime}$ larda mükemmel, $0,80^{\prime}$ lerde çok iyi, 0,70 ve $0,60^{\prime} l a r d a$ vasat, $0,50^{\prime}$ lerde kötü) olduğunu belirtmektedir (Tavşancıl, 2006). Bartlett testi ise analiz sonucunda anlamlı bulunmuştur $(p<0,05)$. Buna göre, değişkenler arasında yeterli korelasyonlar mevcuttur, başka bir deyişle veri seti faktör analizi için uygundur (Kalaycı, 2009). Daha sonra AFA uygulamasına geçilmiştir. Hesaplanan madde faktör yük değerinin genellikle 0,45 ve daha yüksek olması istenmekle birlikte faktör yük değeri 0,30 olan maddeler de ölçekte tutulabilir (Kline, 1994; Tabachnick ve Fidell, 1989). AFA'ya ilişkin maddelerin faktör yük değerleri aşă̆ıda verilmiştir.

Tablo 3. Görsel sanatlar eğitimi uygulamalarında edebiyat ürünlerinin etkisini belirlemeye yönelik dereceli puanlama anahtarına ilişkin faktör yük değerleri

\begin{tabular}{lc}
\hline Maddeler & Faktör Yük Değerleri \\
\hline 1. Bütünlük ve görsel devamlılık & 0,928 \\
2. Hareket ifadesi & 0,810 \\
3. İmge kullanımı (imge çeşitliliği ve zenginliği) & 0,897 \\
4. Renk kullanımı (renk zenginliği) & 0,844 \\
5. Ayrıntılara (detaya) yer verme & 0,836 \\
6. Mekân ifadesi & 0,666 \\
7. Kompozisyon & 0,929 \\
8. Yaratıcı düşünme (özgün ifade) & 0,948 \\
9. Stereotip biçim kullanımı & 0,916 \\
\hline
\end{tabular}

Uygulanan AFA sonucunda ölçme aracının tek bir temel yapıyı ölçtüğü ve öğrenci resimlerinin ürün performansının ölçülmesine ilişkin varyansın \%79,60'ını açıkladığı tespit edilmiştir. Büyüköztürk (2012), tek faktörlü ölçeklerde açıklanan varyansın \%30 ve daha fazla olmasının yeterli görülebileceğini ifade etmektedir. Başka bir deyişle ölçme aracının her bir maddesi, içeriğin genel amacı olan ölçme amacına yüksek oranda hizmet etmektedir.

Daha sonra uygulanan DFA sonucunda ölçeğe ait uyum indeksleri; $\chi^{2} / s d=1,49, \mathrm{RMSEA}=0,17, \mathrm{SRMR}=0,08, \mathrm{NNFI}=0,91, \mathrm{CFI}=0,94$, $\mathrm{GFI}=0,99, \mathrm{AGFI}=0,98$ olarak hesaplanmıştır. $\chi^{2} / s d$ değerinin 1 ile 3 arasında olması mükemmel uyumu gösterir (Kline, 2011, s.204). Ayrıca RMSEA $\leq 0,10$ olması vasat uyumu, SRMR $<0,10$ kabul edilebilir uyumu, $0,90<\mathrm{NNFI}$ ve $\mathrm{CFI}<0,94$ olması kabul edilebilir uyumu, GFI ve AGFI > 0,45 olması kabul edilebilir uyumu ifade etmektedir (Çelik ve Yılmaz, 2013). Bu sonuçlar incelendiğinde, rubriğin genel anlamda iyi uyum değerlerine sahip olduğu ve tek boyuta sahip bir model olarak doğrulandığı görülmektedir. Rubriğin DFA sonucuna ait yol diyagramı aşağıda verilmiştir. 


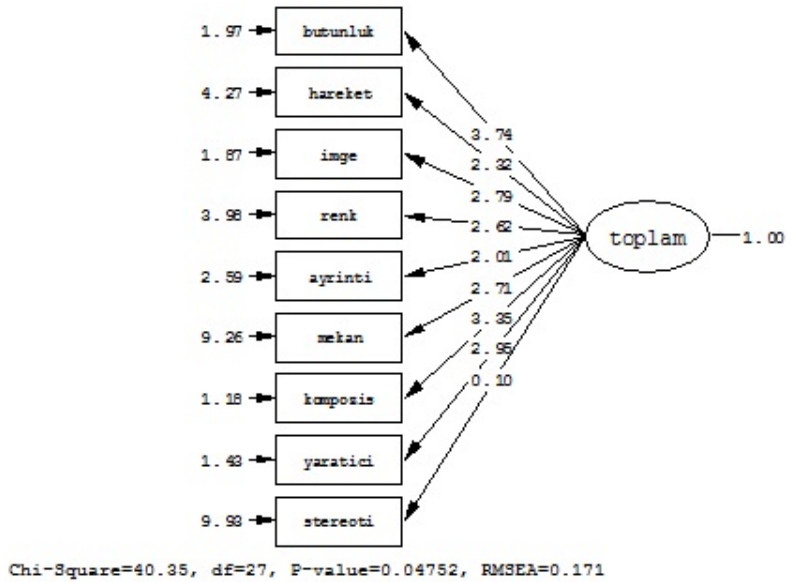

Şekil 2. Görsel sanatlar eğitimi uygulamalarında edebiyat ürünlerinin etkisini belirlemeye yönelik dereceli puanlama anahtarına ilişkin dfa sonuçları: Yol diyagramı

Geçerlik analizlerinden elde edilen değerler incelendiğinde, tüm maddelerin ölçme aracında kalması gerektiği sonucuna ulaşılmıştır.

Rubriklerin güvenirliğinin sağlanmasında puanlayıcılar arası uyuşmaya bakılması önerilmektedir (Moskal ve Leydens, 2000). Bu nedenle puanlama sonuçlarından Kappa analizleri yapılarak rubriğe ait güvenirlik sonuçları elde edilmiştir. Kappa katsayısından elde edilen veriler "Zayıf uyuşma=0,00-0,20; Kabul edilebilir uyuşma=0,20-0,40; Orta derecede uyuşma=0,40-0,60; İyi uyuşma=0,60-0,80; Çok iyi uyuşma=0,80-1,00" olarak yorumlanmaktadır (Şencan, 2005).

Tablo 4. Görsel sanatlar eğitimi uygulamalarında edebiyat ürünlerinin etkisini belirlemeye yönelik dereceli puanlama anahtarına ilişkin puanlayıcılar arası uyumuna ait kappa katsayısı sonuçları

\begin{tabular}{llllll}
\hline Kappa uyum ölçümü & $n$ & Değer & Asimptotik standart hata & $T^{\text {b }}$ & $p$ \\
\hline 1.-2. Uzmanlar & 18 & 0,719 & 0,125 & 6,037 & $0,00^{*}$ \\
1.-3. Uzmanlar & 18 & 0,789 & 0,111 & 6,571 & $0,00^{*}$ \\
2.-3. Uzmanlar & 18 & 0,788 & 0,111 & 6,582 & $0,00^{*}$ \\
\hline
\end{tabular}

$* \mathrm{p}<0,05$

Tablo 4 incelendiğinde, Kappa uyum ölçüm değerlerinin anlamlı olduğu $(p<0,05)$ ve uzmanların görüşlerinin birbirleri ile iyi uyuşma içinde oldukları söylenebilir. Daha sonra puanlayıcılar arası korelasyon değerleri incelenmiştir. Bu analize ilişkin sonuçlar aşağıda verilmiştir.

Tablo 5. Görsel sanatlar eğitimi uygulamalarında edebiyat ürünlerinin etkisini belirlemeye yönelik dereceli puanlama anahtarına ilişkin puanlayıcılar arası korelasyon değerleri

\begin{tabular}{llll}
\hline Faktör & Uzman 1 & Uzman 2 & Uzman 3 \\
\hline Uzman 1 & - & & \\
Uzman 2 & $0,93^{* *}$ & - & - \\
Uzman 3 & $0,96^{* *}$ & $0,96^{* *}$ & - \\
\hline
\end{tabular}

$* * p<0,01$

Tablo 5 incelendiğinde, puanlayıcılar arası korelasyon değerlerinin 0,93 ile 0,96 arasında değiş̧iği görülmektedir. Ölçeğin geneli için hesaplanan Cronbach Alpha güvenirlik katsayısı ise 0,98'dir. Psikolojik bir test için hesaplanan güvenirlik katsayısının 0,70 ve daha yüksek olması test puanlarının güvenirliği için yeterli görülmektedir (Büyüköztürk, 2012). Başka bir anlatımla, puanlayıcıların aynı öğrencileri benzer şekilde puanladıkları ve tüm maddelerin güvenilir sonuçlar verdiği tespit edilmiştir.

\section{Verilerin Analizi}

Öğrenci çalışmaları; alan uzmanı üç akademisyen tarafından dereceli puanlama anahtarı (rubrik) kriterlerine dayalı olarak puanlanmıştır. Öğrenci çalışmalarına verilen puanlar bilgisayar ortamına geçirilmiş ve verilerin analizinde "SPSS" paket programı kullanılarak araştırmanın bulgularına ulaşıımıştır. Araştırmada kullanılan dereceli puanlama anahtarına ait öntest ve sontest puanlarının karşılaştırılması, Wilcoxon işaretli sıralar testi ile gerçekleştirilmiştir. Anlamlılık düzeyi p<0.05 olarak esas alınmıştır.

Wilcoxon eşleştirilmiş çiftler testi olarak da bilinen bu test; ilişkili iki ölçüm setine ait puanlar arasındaki farkın anlamlılığını test etmek için kullanılır. Bu teknik sosyal bilimlerde az denekle gerçekleştirilen gruplar içi çalışmalarda sıklıkla kullanılır. Deneklerin fark puanlarının normal dağılım göstermediği şartlarda ilişkili örneklem t-testinin yerine tercih edilir. Burada eşleştirilmiş iki grup üzerinde ya da aynı denekler üzerinde iki farklı zamanda yapılan ölçümlerden elde edilen puanlar analize tabi tutulur (Büyüköztürk, 
2012, s.162-163). Ayrıca öntest ve sontest çalışmalarının geneli betimsel olarak yorumlanmıştır. Öğrenci çalışmaları Ek' de görülmektedir.

\section{BULGULAR}

Uzmanların öğrenci çalışmalarına dereceli puanlama anahtarı (rubrik) üzerinde vermiş oldukları puanların öntest-sontest sonuçlarına göre; edebiyat ürünlerinin görsel sanat çalışmalarına etkisine yönelik Wilcoxon Testine ilişkin bulgular aşağıda verilmiştir.

Tablo 6. Edebiyat ürünlerinin bütünlük ve görsel devamlılık kriteri açısından wilcoxon testine ilişkin bulguları

\begin{tabular}{lccccc}
\hline Sontest-öntest & $n$ & Sıra ortalaması & Sıra toplamı & $Z$ & $0,00^{*}$ \\
\hline Negatif sıra & 0 & 0,00 & 0,00 & 6,18 & \\
Pozitif sıra & 50 & 25,50 & 25,50 & & \\
Eşit & 0 & - & - & \\
\hline
\end{tabular}

$* \mathrm{p}<0,05$

Tablo 6 incelendiğinde, araştırmaya katılan öğrencilerin rubriğin bütünlük ve görsel devamlılık maddesinden aldıkları öntest ve sontest puanları arasında anlamlı bir fark olduğu görülmektedir $(Z=6,18, p<0,05)$. Fark puanlarının sıra ortalaması ve toplamları dikkate alındığında, gözlenen bu farkın pozitif sıralar, yani sontest puanı lehine olduğu görülmektedir.

Tablo 7. Edebiyat ürünlerinin hareket ifadesi kriteri açısından wilcoxon testine ilişkin bulguları

\begin{tabular}{lccccc}
\hline Sontest-öntest & $n$ & Sıra ortalaması & Sıra toplamı & Z & $0,00^{*}$ \\
\hline Negatif sıra & 1 & 2,00 & 2,00 & 6,09 & \\
Pozitif sıra & 48 & 25,48 & 12,23 & & \\
Eşit & 1 & - & - & \\
\hline
\end{tabular}

${ }^{*} p<0,05$

Tablo 7 incelendiğinde, araştırmaya katılan öğrencilerin rubriğin hareket ifadesi maddesinden aldıkları öntest ve sontest puanları arasında anlamlı bir fark olduğu görülmektedir $(Z=6,09, p<0,05)$. Fark puanlarının sıra ortalaması ve toplamları dikkate alındığında, gözlenen bu farkın pozitif sıralar, yani sontest puanı lehine olduğu görülmektedir.

Tablo 8. Edebiyat ürünlerinin imge kullanımı kriteri açısından wilcoxon testine ilişkin bulguları

\begin{tabular}{lccccc}
\hline Sontest-öntest & $n$ & Sıra ortalaması & Sıra toplamı & $Z$ & $p$ \\
\hline Negatif sıra & 0 & 0,00 & 0,00 & 6,18 & $0,00^{*}$ \\
Pozitif sıra & 50 & 25,50 & 1275,00 & & \\
Eşit & 0 & - & - & & \\
${ }^{*} \mathrm{p}<0,05$ & & &
\end{tabular}

Tablo 8 incelendiğinde, araştırmaya katılan öğrencilerin rubriğin imge kullanımı maddesinden aldıkları öntest ve sontest puanları arasında anlamlı bir fark olduğu görülmektedir $(Z=6,18, p<0,05)$. Fark puanlarının sıra ortalaması ve toplamları dikkate alındığında, gözlenen bu farkın pozitif sıralar, yani sontest puanı lehine olduğu görülmektedir.

Tablo 9. Edebiyat ürünlerinin renk kullanımı kriteri açısından wilcoxon testine ilişkin bulguları

\begin{tabular}{lccccc}
\hline Sontest-öntest & $n$ & Sıra ortalaması & Sıra toplamı & Z & $0,00^{*}$ \\
\hline Negatif sıra & 0 & 0,00 & 0,00 & 6,18 & \\
Pozitif sıra & 50 & 25,50 & 1275,00 & & \\
Eşit & 0 & - & - & \\
${ }^{*} \mathrm{p}<0,05$ & & & &
\end{tabular}

Tablo 9 incelendiğinde, araştırmaya katılan öğrencilerin rubriğin renk kullanımı maddesinden aldıkları öntest ve sontest puanları arasında anlamlı bir fark olduğu görülmektedir $(Z=6,18, p<0,05)$. Fark puanlarının sıra ortalaması ve toplamları dikkate alındığında, gözlenen bu farkın pozitif sıralar, yani sontest puanı lehine olduğu görülmektedir.

Tablo 10. Edebiyat ürünlerinin ayrıntılara yer verme kriteri açısından wilcoxon testine ilişkin bulguları

\begin{tabular}{lccccc}
\hline Sontest-öntest & $n$ & Sıra ortalaması & Sıra toplamı & $Z$ & 0 \\
\hline Negatif sıra & 1 & 2,00 & 2,00 & 6,16 & $0,00 *$ \\
Pozitif sıra & 49 & 25,98 & 1273,00 & & \\
Eşit & 0 & - & - & & \\
\hline$*$ p & 0 & & & & \\
\hline
\end{tabular}

$$
\text { *p<0,05 }
$$


Tablo 10 incelendiğinde, araştırmaya katılan öğrencilerin rubriğin ayrıntılara yer verme maddesinden aldıkları öntest ve sontest puanları arasında anlamlı bir fark olduğu görülmektedir $(Z=6,16, p<0,05)$. Fark puanlarının sıra ortalaması ve toplamları dikkate alındığında, gözlenen bu farkın pozitif sıralar, yani sontest puanı lehine olduğu görülmektedir.

Tablo 11. Edebiyat ürünlerinin mekân ifadesi kriteri açısından wilcoxon testine ilişkin bulguları

\begin{tabular}{lccccc}
\hline Sontest-öntest & $n$ & Sıra ortalaması & Sıra toplamı & Z & $0,00 *$ \\
\hline Negatif sıra & 1 & 3,50 & 3,50 & 5,88 & \\
Pozitif sıra & 45 & 23,94 & 1077,50 & & \\
Eşit & 4 & - & - & & \\
\hline
\end{tabular}

${ }^{*} \mathrm{p}<0,05$

Tablo 11 incelendiğinde, araştırmaya katılan öğrencilerin rubriğin mekân ifadesi maddesinden aldıkları öntest ve sontest puanları arasında anlamlı bir fark olduğu görülmektedir $(Z=5,88, p<0,05)$. Fark puanlarının sıra ortalaması ve toplamları dikkate alındığında, gözlenen bu farkın pozitif sıralar, yani sontest puanı lehine olduğu görülmektedir.

Tablo 12. Edebiyat ürünlerinin komposizyon kriteri açısından wilcoxon testine ilişkin bulguları

\begin{tabular}{lccccc}
\hline Sontest-öntest & $n$ & Sıra ortalaması & Sıra toplamı & Z & $p$ \\
\hline Negatif sıra & 0 & 0,00 & 0,00 & 6,18 & $0,00 *$ \\
Pozitif sıra & 50 & 25,50 & 1275,00 & & \\
Eşit & 0 & - & - & & \\
${ }^{*} \mathrm{p}<0,05$ & & &
\end{tabular}

Tablo 12 incelendiğinde, araştırmaya katılan öğrencilerin rubriğin kompozisyon maddesinden aldıkları öntest ve sontest puanları arasında anlamlı bir fark olduğu görülmektedir $(Z=6,18, p<0,05)$. Fark puanlarının sıra ortalaması ve toplamları dikkate alındığında, gözlenen bu farkın pozitif sıralar, yani sontest puanı lehine olduğu görülmektedir.

Tablo 13. Edebiyat ürünlerinin yaratıcı düşünme kriteri açısından wilcoxon testine ilişkin bulguları

\begin{tabular}{lccccc}
\hline Sontest-öntest & $n$ & Sıra ortalaması & Sıra toplamı & Z & 0 \\
\hline Negatif sıra & 0 & 0,00 & 0,00 & 6,14 & $0,00^{*}$ \\
Pozitif sıra & 49 & 25,00 & 1225,00 & & \\
Eşit & 1 & - & - & & \\
${ }^{*}$ p $<0,05$ & & & &
\end{tabular}

Tablo 13 incelendiğinde, araştırmaya katılan öğrencilerin rubriğin yaratıcı düşünme maddesinden aldıkları öntest ve sontest puanları arasında anlamlı bir fark olduğu görülmektedir $(Z=6,14, p<0,05)$. Fark puanlarının sıra ortalaması ve toplamları dikkate alındığında, gözlenen bu farkın pozitif sıralar, yani sontest puanı lehine olduğu görülmektedir.

Tablo 14. Edebiyat ürünlerinin stereotip biçim kullanımı kriteri açısından wilcoxon testine ilişkin bulguları

\begin{tabular}{lccccc}
\hline Sontest-öntest & $n$ & Sıra ortalaması & Sıra toplamı & Z & $p$ \\
\hline Negatif sıra & 0 & 0,00 & 0,00 & 5,94 & $0,00 *$ \\
Pozitif sıra & 46 & 23,50 & 1081,00 & & \\
Eşit & 4 & - & - & \\
${ }^{*} p<0,05$ & & &
\end{tabular}

Tablo 14 incelendiğinde, araştırmaya katılan öğrencilerin rubriğin stereotip biçim kullanımı maddesinden aldıkları öntest ve sontest puanları arasında anlamlı bir fark olduğu görülmektedir $(Z=5,94, p<0,05)$. Fark puanlarının sıra ortalaması ve toplamları dikkate alındığında, gözlenen bu farkın pozitif sıralar, yani sontest puanı lehine olduğu görülmektedir.

Bu bulgulara göre; edebiyat ürünleri, bütünlük ve görsel devamlılık, hareket ifadesi, imge kullanımı, renk kullanımı, ayrıntılara yer verme, mekân ifadesi, kompozisyon, yaratıcı düşünme ve stereotip biçim kullanımı kriterleri üzerinde önemli bir etkiye sahiptir.

\section{Öntest ve Sontest'e Ait Öğrenci Çalışmalarına Yönelik Betimsel Analiz ve Yorumlar}

Bütünlük ve görsel devamlılık kriteri açısından; öntest çalışmasına ait resimlerde unsurlar daha çok rastgele, dağınık şekilde ve özensiz yerleştirilmiş iken (bakınız Resim No: 1, 5, 9, 13 vb. gibi), sontest 1, sontest 2 ve sontest 3 çalışmalarına ait resimlerin çoğunda gözün takip edebileceği, görsel bir devamlılık oluşturacak ve düzende birliği sağlayacak şekilde yerleştirme yapıldığı dikkati çekmektedir. Bu duruma örnek sontest 1 (bakınız Resim No: 2, 10, 18, 22, 26, 30 vb. gibi), sontest 2 (bakınız Resim No: 3 , 7, 11, 15, 19, 23, 27 vb. gibi) ve sontest 3 (bakınız Resim No: 4, 8, 16, 20, 24, 28, 32 vb. gibi) çalışmalarına ait resimlerde görülmektedir.

Hareket ifadesi kriteri açısından; öntest çalışmasına ait resimlerde çizilmiş olan unsurlar ve figürlerin tamamına yakını statik, aynı yöne bakmakta ve hareketten yoksun bir duruş sergilemektedir. Çalışmaların çok azında hafif bir hareket etkisi görülmektedir (bakınız Resim No: 1, 5, 9, 13, 17, 21, 25, 29). Öntest çalışmalarının aksine sontest 1 çalışmalarında havada uçan kazlar ve kaplumbağa, uçan kazların kanat hareketleri (bakınız Resim No: 14 ve 26), başı yere eğik geyiğin boyun ve vücut hareketleri, aslanın 
geyiği takip hareketi (bakınız Resim No: 2, 10, 22, 30), tilkinin tarlada veya kümes etrafında saklanması, (bakınız Resim No: 18) vb. gibi hareketler dikkati çekmektedir. Aynı zamanda kompozisyonu oluşturan unsurların yerleştirilmesinde de hareket etkisi etkili bir şekilde görülmektedir. Öntest çalışmalarının aksine sontest 2 çalışmalarında kayıkta kürek çeken insan (bakınız Resim No: 3, 7, 19 vb. gibi), aynadan kendini izleyen karganın kekliği taklit etme hareketi (bakınız Resim No: 11), ağaca ve kayanın üzerine çıkmış keçiler (bakınız Resim No: 23, 27), devenin çam ve çardak deviren hareketi (bakınız Resim No: 31), vb. gibi resim örnekleri dikkat çekmektedir. Sontest 2 çalışmalarında ayrıca mekâna dair hareket verilmeye çalışılmıştır. Örneğin denizin dalgalı ve rüzgarlı olması hareketi (bakınız Resim No: 3, 19 vb. gibi), yaprakların, kağıt vb. gibi unsurların havada uçuşma hareketi (bakınız Resim No: 11, 15 vb. gibi) dikkat çekmektedir. Öntest çalışmalarının aksine sontest 3 çalışmalarında havada uçan doğa üstü varlıklar örneğin periler, insanlar, objeler, uçan kuşlar veya tanımlanamayan doğa üstü varlıkların kanat ya da kuyruk hareketleri (bakınız Resim No: 8, 12, $16,20,24,28,32$ ) dikkat çekici olarak görülmektedir. Aynı zamanda kompozisyonu oluşturan unsurların yerleştirilmesinde de hareket etkisi etkili bir şekilde görülmektedir.

İmge kullanımı kriteri açısından; öntest çalışmasına ait resimlerde klasik olarak ağaç, dağ, tepe, akarsu vb. kullanılmış, bulut ve güneş ile gökyüzü ifadesi verilmeye çalışılmış, oldukça az çeşitte ve bilindik imgeler kullanılmıştır (bakınız Resim No: 1, 5, 9, 13, 21, 25 vb. gibi). Sontest 1 çalışmalarında ise; duygu ve düşüncelerin ifadesinde biçimlerde çeşitlilik ve zenginlik söz konusudur (bakınız Resim No: 6, 10, 18, 22, 26, 30 vb. gibi). İmge çeşitliliğine örnek olarak göl kenarında yansımasını izleyen geyik (bakınız Resim No: 10), kaplumbağa ve kazlarla insanların diyaloğu (bakınız Resim No: 14), tavuk ile horozun karşılıklı diyaloğu (bakınız Resim No: 18), vb. gibi ifadeler görülmektedir. Ayrıca bitkilerde tarla bitkileri (lahana vb.), orman çalıları ve orman ağaçları (çam ağacı vb.) gibi çeşitlilik dikkat çekmektedir. Sontest 2 çalışmalarında ise; duygu ve düşüncelerin ifadesinde biçimlerde çeşitlilik ve zenginlik söz konusudur (bakınız Resim No: 3, 7, 11, 15, 19, 23, 27, 31 vb. gibi). Örnek olarak kayıkta kürek çeken insan resmi (bakınız Resim No: 3, 7, 19 vb. gibi), başına devlet kuşu konmuş insan resmi (bakınız Resim No: 15), karga figürünün imgesel kurgusu (bakınız Resim No: 11), keçi figürlerinin imgesel kurgusu (bakınız Resim No: 23, 27), deve figürünün imgesel kurgusu (bakınız Resim No: 31), vb. gibi ifade edilen resimler görülmektedir. Sontest 3 çalışmalarında ise; duygu ve düşüncelerin ifadesinde biçimlerde çeşitlilik ve zenginlik söz konusudur. Örnek olarak uçan kitap (bakınız Resim No: 8), renk değiştiren elbise (bakınız Resim No: 12), renkli kar yağdıran kuş (bakınız Resim No: 20), boynuzlu ve kanatlı dev ejderha ile kızın karşılıklı diyaloğu (bakınız Resim No: 24), aslan başlı kral balık ve deniz kızları (bakınız Resim No: 32), ve doğa üstü varlıklar (bakınız Resim No: 8, 16, 20, 24, 28, 32) vb. gibi resimler görülmektedir. Ayrıca imge çeşitliliği bakımından bitki çeşitliliği menekşe, papatya ve denizaltı bitkileri (bakınız Resim No: 28, 32), gibi çeşitlilik dikkat çekmektedir. İmge çeşitliliği bakımından mimari yapılarda genellikle şato, kule, kale, saray vb. gibi çeşitlilik dikkat çekmektedir (bakınız Resim No: 4, 28).

Renk kullanımı kriteri açısından; sontest 1, sontest 2 ve sontest 3 çalışmalarına ait resimlerde renklerin çeşitliliği, zenginliği, renk dengesi ve uyumu açısından öntest çalışmasına ait resimlere oranla daha başarılıdır. Sontest 1 resimlerinin bir kısmında ışık, gölge, ton, valör gibi renk ayrıntılarına girme durumları görülmektedir. Bu duruma örnek sontest 1 (bakınız Resim No: 6, 10, 18, 22, 30 vb. gibi), sontest 2 (bakınız Resim No: 11, 19, 23, 27, 31 vb. gibi) ve sontest 3 (bakınız Resim No: 4, 8, 12, 20, 24, 28, 32 vb. gibi) çalışmalarına ait resimlerde görülmektedir. Öntest çalışmasına ait resimlerde bu durum daha az dikkat çeken bir unsur olarak karşımıza çıkmaktadır (bakınız Resim No: 1, 17, 21, 25 vb. gibi). Öntest çalışmasına ait resimlerde renk kullanımı kriteri açısından sadece birkaç resim başarı göstermektedir.

Ayrıntılara yer verme kriteri açısından; öntest çalışmasına ait resimlere oranla sontest 1, sontest 2 ve sontest 3 çalışmalarına ait resimlerin çoğunluğunda figürlerin türüne özgü anatomik ve karakteristik detayların etkili şekilde verildiği görülmektedir. Sontest 1 çalışmalarına örnek olarak öntest çalışmalarına oranla daha başarılı çalışmaların olduğu görülmektedir (bakınız Resim No: 2, 6, 10, 18, 22, 26, 30). Örneğin hayvan figürlerinden tilki figürünün burnunun sivriliği, kulaklarının dikliği, iri gözleri, kuyruk gibi anatomik ayrıntıları, horoz figürünün gözleri, gagası, ibiği, renkli tüyleri gibi anatomik ayrıntıları (bakınız Resim No: 18), kaz figürünün gözleri, gagası, ibiği, tüyleri, perdeli ayakları, havada uçarken kanatlarının ayrıntıları ve diğer anatomik ayrıntıları, kaplumbağa figürünün sırtındaki kabuğu, ayakları, ağzı ve gözleri gibi anatomik ayrıntıları (bakınız Resim No: 14 ve 26), aslan figürünün burnu, ağzı, kulakları, kuyruğu, ayakları, pençesi, yelesinin gerçekçi ifadesi ve diğer anatomik ayrıntıları (bakınız Resim No: 2, 6, 22, 30), geyik figürünün gözleri, burnu, ağzı, kulakları, kuyruğu, boynuzları, bacaklarının uzunluğu ve diğer anatomik ayrıntıları (bakınız Resim No: 10, 22, 30), sontest 1 çalışmalarında dikkat çeken detaylardır. Ayrıca sontest 1 çalışmasında geyiğin mekândaki su üzerinde yüzünün yansıması (bakınız Resim No: 10 ve 30), mekândaki lahana tarlasında tilkinin saklanması (bakınız Resim No: 18), gökyüzünde uçan kazlar ve yeryüzündeki mekân ayrıntıları (bakınız Resim No: 26) verilmeye çalışılmıştır. Sontest 2 çalışmalarına örnek olarak öntest çalışmalarına oranla daha başarılı çalışmaların olduğu görülmektedir (bakınız Resim No: 3, 11, 15, 19, 23, 27, 31 vb. gibi.). Örneğin hayvan figürlerinden keçi figürünün boynuzlarının sivriliği ve kıvrımı, gözleri, sakalı, bacakları ve kuyruğu gibi anatomik ayrıntıları (bakınız Resim No: 23, 27 vb. gibi), deve figürünün hörgücü, boynunun uzunluğu, ayakları, bacaklarının inceliği ve uzunluğu, kulakları ve yüzü gibi anatomik ayrıntıları (bakınız Resim No: 31 vb. gibi), karga ve kekliğin gagası, gözleri, kekliğin renkli tüyleri gibi anatomik ayrıntıları (bakınız Resim No: 11 vb. gibi), insan figürlerinin yüz ifadeleri, saç, kaş, göz, burun, ağız, vb. gibi karakteristik ayrıntıları (bakınız Resim No: 3, 7, 15, 19 vb. gibi), sontest 2 çalışmalarında dikkat çeken detaylardır. Ayrıca ağaç, çiçek, çalı gibi bitkilerin yaprak ve biçim ayrıntıları (bakınız Resim No: 7, 11, 23, 27 vb. gibi), ağaç yapraklarının savrulması, dökülmesi (bakınız Resim No: 11) vb. ifade edilmeye çalışımıştır. Sontest 2 çalışmalarında denizin dalgalı ve rüzgarlı olması gibi mekâna ait ayrıntılar (bakınız Resim No: 19 vb. gibi), mekânda bulunan evler, ağaçlar vb. gibi unsurların detayına girilerek mekân ayrıntıları verilmeye çalışılmıştır (bakınız Resim No: 23 vb. gibi). Sontest 3 çalışmalarına örnek olarak öntest çalışmalarına oranla daha başarılı çalışmaların olduğu görülmektedir (bakınız Resim No: 12, 16, 20, 24, 32 vb. gibi). Örneğin insan figürlerinin kol, bacak, kafa vb. gibi anatomik ayrıntıları ve kıyafet ayrıntıları (bakınız Resim No: 3, 24, 28, 32 vb. gibi), hayvan

|Kastamonu Eğitim Dergisi, 2020, Vol. 28, No. 5 | 
figürlerinden kuş figürlerinin gagası, gözü, tüyleri, kuyruğu ve kanat gibi anatomik ayrıntıları (bakınız Resim No: 20 vb. gibi), ejderha figürlerinin kafa, göz, diş, burun, kuyruk, bacak, kanat gibi unsurların gerçekçi ayrıntıları, sırtındaki ve ayak tırnaklarındaki dikensi ayrıntıları vb. gibi diğer anatomik ayrıntılar (bakınız Resim No: 24 vb. gibi), balık figürleri ve denizaltı canlılarının baş, yüzgeç, kuyruk vb. gibi anatomik ayrıntıları (bakınız Resim No: 32), sontest 3 çalışmalarında dikkat çekici ayrıntılar olarak görülmektedir. Ayrıca sontest 3 çalışmalarında deniz altında bir mekân resmi (bakınız Resim No: 32 vb. gibi), yer yüzünde ayrıntılı bir mekân (bakınız Resim No: 24) vb. gibi çeşitli mekân ayrıntıları verilmeye çalışılmıştır. Öntest çalışmasına ait resimlerde ayrıntılara yer verme kriteri açısından oldukça az resim başarı göstermektedir (bakınız Resim No: 17, 21, 25 vb. gibi).

Mekân ifadesi kriteri açısından; öntest çalışmasına ait resimlere oranla sontest 1, sontest 2 ve sontest 3 çalışmalarına ait resimlerin çoğunluğunda mekân ifadesi daha etkilidir. Sontest 1 çalışmalarında güneş, bulut, dağ, akarsu vb. unsurlarda tonlamalarla derinlik ve üç boyutluluk etkisinin verilmeye çalışıldığı görülmektedir. Örneğin, arka planda gün batımı, bulutlu hava ve yoğun ormanlık alan (bakınız Resim No: 2, 18, 22, 30) etkisi vb. oluşturarak ön plan-arka plan ifadesinin daha etkili şekilde verildiği görülmektedir. Sontest 2 çalışmalarında güneş, bulut, dağ, akarsu vb. unsurlarda tonlamalarla derinlik ve üç boyutluluk etkisinin verilmeye çalışıldığı görülür. Örneğin, akarsu ya da denizden oluşan bir mekân (bakınız Resim No: 3, 7, 19 vb. gibi), arka planda gün batımı (bakınız Resim No: 3, 23 vb. gibi), ve özellikle arka fon oluşturularak yapılmış bir mekân ifadesi ile ön plan-arka plan ifadesinin daha etkili şekilde verildiği görülmektedir (bakınız Resim No: 3, 11, 23, 27 vb. gibi). Sontest 3 çalışmalarında yeryüzü resmedilmiş bir mekânda güneş, bulut, dağ, akarsu vb. gibi çevredeki unsurlarda tonlamalarla derinlik ve üç boyutluluk etkisinin verilmeye çalışıldığı görülür (bakınız Resim No: 4, 8, 24, 28, 32 vb. gibi). Örneğin, arka planda gün batımı ve bulutlu hava (bakınız Resim No: 8, 24, 28 vb. gibi), gökyüzüne ait mekân çeşitleri (bakınız resim No: 8, 20 vb. gibi), deniz altına ait mekân ifadesi (bakınız Resim No: 32 vb. gibi) oluşturarak ön plan-arka plan ifadesinin daha etkili şekilde verildiği görülmektedir. Öntest çalışmasına ait resimlerde mekân ifadesi kriteri açısından oldukça az resim başarı göstermektedir (bakınız Resim No: 21, 25 vb. gibi).

Kompozisyon kriteri açısından; öntest çalışmasına ait resimlere oranla sontest 1, sontest 2 ve sontest 3 çalışmalarına ait resimlerin çoğunluğunda kullanılan unsurlarda, kompozisyon ilkelerine uygunluğu açısından daha başarılı düzenlemelerin olduğu görülmektedir. Bu duruma ait örnek sontest 1 (bakınız Resim No: 2, 10, 18, 26), sontest 2 (bakınız Resim No: 3, 7, 11, 15, 19, 23, $27 \mathrm{vb}$. gibi) ve sontest 3 (bakınız Resim No: 4, 8, 12, 16, 20, 24, 28, 32 vb. gibi) çalışmalarına ait resimlerde görülmektedir. Öntest çalışmasına ait resimlerde kompozisyon kriteri açısından oldukça az resim başarı göstermektedir (bakınız Resim No: 17, 21, 25 vb. gibi).

Yaratıcı düşünme kriteri açısından; öntest çalışmasına ait resimlerde klasik, tek düze, ezbere çizilmiş ve özensiz unsurlardan oluşan resimlerin varlığı dikkati çekmektedir (bakınız Resim No: 1, 5, 9, 13, 21, 25 vb. gibi). Sontest 1, sontest 2 ve sontest 3 çalışmalarında konunun daha farklı yaklaşımlarla ele alındığı ve bir konuya bağlı olarak kurgulanan, özgün bir şekilde ifade edilmiş resimler görülmektedir. Sontest 1 çalışmalarında örneğin tilkinin lahana tarlasında saklanıp kümes hayvanlarını izlemesi (bakınız Resim No: 18), aslanın geyiğin üzerine doğru gelmesi veya kovalaması (bakınız Resim No: 2, 22, 30 vb. gibi), kazların kaplumbağayı havada uçurması (bakınız Resim No: 14, 26), vb. gibi özgün şekilde ifade edilmiş resimler görülmektedir. Sontest 2 çalışmalarında ise; örneğin kekliği taklit eden karga, karganın aynadan kendisine bakması (bakınız Resim No: 11), ağaca çıkan keçi (bakınız Resim No: 23, 27 vb. gibi), çam ağacı ve çardak deviren deve (bakınız Resim No: 31 vb. gibi), başına talih kuşu konan insan figürü (bakınız Resim No: 15 vb. gibi), akıntıya kürek çeken insan figürleri (bakınız Resim No: 3, 7, 19) vb. gibi özgün şekilde ifade edilmiş resimler görülmektedir. Sontest 3 çalışmalarında ise; örneğin doğa üstü varlıkların, hayvanların ve insanların iletişim içerisinde olduğunu gösteren, kendi aralarındaki diyalogları (bakınız Resim No: 24, 32 vb. gibi), kralın kayığın içerisinde telaşla etrafa bakması (bakınız Resim No: 4), uçan kitap (bakınız Resim No: 8), renk değiştiren bir elbise (bakınız Resim No: 12), hediye paketi dağıtan hediye kuşu (bakınız Resim No: 16), uçarken ardından renkli kar yağdıran kuş (bakınız Resim No: 20), boynuzlu ve kanatlı dev ejderha ile kız (bakınız Resim No: 24), aslan başlı kral balığı ve deniz kızları (bakınız Resim No: 32) ve doğa üstü varlıklar (bakınız Resim No: 8, 12, $16,20,24,28,32$ ) gibi özgün şekilde ifade edilmiş resimler görülmektedir.

Stereotip biçim kullanımı kriteri açısından, öntest çalışmasına ait resimlerde ezbere çizilmiş, ' $M$ ' ve ' $V$ ' harfi şeklinde kuşlar, üçgen çatılı evler, ' $M$ ' şeklinde veya üçgenlerden ya da yarım dairelerin yan yana birleşiminden oluşan dağlar, kıvrımlı veya düz çizgilerden oluşturulan ezbere çizilen akarsu veya gölet çizimleri, ışınları bir uzun bir kısa çizgilerin tekrarından oluşan ya da gülen yüz gibi ezber çizimlerden oluşan şablon güneş motifi, yuvarlak ve oval şekillerden oluşan ezbere çizilmiş bulut motifleri, yuvarlak biçimde, geometrik ve oval şekillerden ya da üçgen şekillerden oluşan ağaçlar, minik dairelerin ve geometrik şekillerin bir araya gelmesinden oluşan papatya, menekşe vb. gibi çiçek ve bitki biçiminde ezbere çizilmiş olan stereotip biçimlerin oldukça çok kullanıldığı görülmektedir (bakınız Resim No: 1, 5, 9, 13, 21, 25 vb. gibi). Öntest çalışmalarında, stereotip biçimde unsurların kullanımı az ya da çok tüm çalışmalarda mevcutken, sontest 1, sontest 2 ve sontest 3 çalışmalarında ise, stereotip biçimlerin çok daha az kullanıldığı görülmektedir. Bu duruma örnek sontest 1 (bakınız Resim No: 2, 14, 26), sontest 2 (bakınız Resim No: 3, 27) ve sontest 3 (bakınız Resim No: 16, 28) çalışmalarına ait resimlerde görülmektedir. Sontest çalışmalarındaki numaraları verilmiş resimlerin dışında kalan çalışmalarda stereotip biçim kullanımı yok denecek kadar azdır.

\section{SONUÇ VE TARTIŞMA}

Görsel sanatlar eğitimi dersindeki öğrenci uygulamalarında edebiyat ürünlerinden yararlanma sonucunda; bütünlük ve görsel devamlılık, hareket ifadesi, imge kullanımı, renk kullanımı, ayrıntılara yer verme, mekân ifadesi, kompozisyon, yaratıcı düşünme ve stereotip biçim kullanımı kriterleri açısından, yani kriterlerin tamamında sontest lehine anlamlı bir fark ortaya çıkmıştır. Yani 
edebiyat ürünlerinin tüm kriterler açısından, öğrencilerin başarı düzeylerini artırmada önemli bir etkiye sahip olduğu söylenebilir. Bu durum, görsel sanatlar dersinde edebiyat ürünlerinden yararlanma yoluna gidilmesinin önemli olduğunu göstermektedir.

İlgili alan yazın tarandığında görsel sanatlar eğitimi alanında bu araştırmayla benzer nitelik taşıyan İnceağaç ve Yılmaz (2018)'a ait "Fabl Türünün 7. Sınıf Öğrencilerinin Görsel Sanat Çalışmalarına Etkisi” başlıklı makale çalışmasında, edebiyat ürünlerinden olan fabl türünün görsel sanat çalışmalarına etkisini ölçmeye yönelik bir araştırma yapıldığı görülmektedir. Araştırmanın, 2015-2016 eğitim öğretim yılında deney ve kontrol grubu olarak 7. sınıf öğrencilerine uygulandığı görülmektedir. Yılmaz ve İnceağaç (2017)'ın "Görsel Sanatlar Eğitimi Uygulamalarında Edebiyat Ürünlerinin Etkisini Belirlemeye Yönelik Dereceli Puanlama Anahtarının (rubrik) Geliştirilmesi" çalışmasında oluşturulan rubrik, bu çalışmada da ölçekte herhangi bir değişiklik yapılmadan kullanılmıştır. Araştırmanın, Mann Whitney U-Testi sonuçlarına göre analiz edildiği görülmektedir. Analiz sonuçlarına göre adı geçen makale çalışmasında, fabl kullanımıyla kriterlerin tamamında deney ve kontrol grupları arasında deney grubu lehine anlamlı bir fark ortaya çıktığı görülmektedir.

Görsel sanatlar eğitimi alanına ait atasözleri ve deyimlerden yararlanma konusunda benzer nitelik taşıyan bir çalışmanın olmadığı görülmektedir. Ancak görsel sanatlar dersinde atasözlerinin kullanımına yönelik olarak Laçinbay ve Yılmaz (2015)'a ait "Türk Atasözlerinden Yararlanarak, Mizahın Görsel Sanatlar Dersinde Kullanımı" başlıklı bildiri özeti türünden bir çalışmanın yapılmış olduğu görülmektedir.

Görsel sanatlar eğitimi alanına ait efsanelerden yararlanma konusunda da benzer nitelik taşıyan bir çalışmanın olmadığı görülmektedir. Ancak efsanelerin tür bakımından destanlara yakın olması nedeniyle konu bakımından benzerlik taşıyan Özkartal (2009)'a ait “ilköğretim Sanat Etkinlikleri Dersinde Dede Korkut Destanının Milli Değerlerin Kazanılmasına Etkisi” başlıklı doktora tez çalışmasında, başarı testi ve tutum ölçeği kullanılarak elde edilen bulgular belirtke tablosu şeklinde verilmiş olup, öğrencilerin uygulama öncesi ve sonrası başarı testi ile tutum ölçeğinden elde edilen sonuçları, frekans ve yüzde değerleri ile ortaya konmuştur. Araştırma sonucunda; deney ve kontrol grupları arasında öntestte anlamlı bir fark ortaya çıkmadığı, ancak sontestte deney grubu lehine anlamlı bir fark ortaya çıktığı görülmektedir. Destanlar edebiyat türlerinden olup, araştırmada elde edilen sonuçları destekler niteliktedir.

Araştırma sonuçlarının, edebiyat ürünlerinin etkisinin taklit ve kopyacılıktan uzak, imgesel açıdan yaratıcı düşünme yetisine sahip ve belirlenmiş sanatsal kriterler üzerinde, başarıyı olumlu yönde etkilediği görülmektedir.

\section{ÖNERILER}

Araştırmanın sonuçlarına dayalı olarak, görsel sanatlar dersinde edebiyat alanının çeşitli türlerine ait ürünlerden sıklıkla yararlanma yoluna gidilmelidir. Edebiyat alanının yararlanılacak olan türü, dersin amaçları doğrultusunda öğrencilerin ihtiyaçlarına ve desteklenmesi gereken hususlara uygun şekilde belirlenmeli ve yine bunlara uygun ürün ve eserler tercih edilmelidir.

Görsel sanatlar dersinde edebiyat ürünlerinden yararlanmada, farklı ve etkili sonuçların ortaya çıkmasına neden olacağı dikkate alınarak değişik yöntemler ve sanatsal tekniklerin kullanımına önem verilmelidir. Örneğin bir efsaneden yarım bırakılan efsaneyi tamamlama, kesit resimleme, imge belirleme, kendi kahramanını oluşturma, mekanların görselleştirilmesi, efsane kahramanlarından üç boyutlu çalışmalar vb. sanatsal tekniklerin ve çeşitli yöntemlerin kullanımı yoluna gidilmelidir.

Disiplinlerarası sanat eğitiminde edebiyat ürünlerinin kullanımına ve etkisine yönelik çalışmaların yetersiz olduğu görülmektedir. Bununla birlikte görsel sanatlar eğitiminde disiplinlerarası yaklaşım üzerine deneysel açıdan sınırlı sayıda çalışmanın olması, bu konuya yeteri kadar önem verilmediği kanısını uyandırmaktadır. Araştırmacılara, görsel sanatlar eğitiminde farklı disiplin alanlarının kullanıldığı çalışmalar üzerine deneysel araştırmalar yapmaları önerilmektedir.

Görsel sanatlar dersinde edebiyat ürünlerinden yararlanma konusunda zaman açısından zorluklar yaşanmış ve pek çok öğrenci çalışmasını bir ders saati sürecinde tamamlayamamıştır. Görsel sanatlar ders saatlerinin artırılması ihtiyacı her vesileyle dile getirildiği gibi, bu vesileyle de bir öneri olarak sunulmaktadır.

\section{Etik Kurul Onay Bilgileri}

Bu araştırma için Kastamonu il Milli Eğitim Müdürlüğü’nden, 28.03.2017 kayıt tarihi ve 75048956-44-E.4175299 sayı numarası ile onay belgesi alınmıştır. Evrak http://evraksorgu.meb.gov.tr adresinden 409f-ba15-313e-b3d0-7de7 kodu ile teyit edilebilir.

\section{KAYNAKÇA}

Avcıoğlu, O. (Ed.) \& Hiperlink (Firm). (2010). Tilkiyle Horoz. (Editör: Osman Avcıoğlu). La Fontaine masalları, içinde (s.49-55), MEB tavsiyeli 100 temel eser. Hazırlayan: Birleşik Yayın Grubu, Eflatun Matbası, İstanbul: Hiperlink. Retrieved from Erişim adresi: <http://search.ebscohost.com/login.aspx?direct=true\&db=nlebk\&AN=702451\&lang=tr\&site=ehost-live> (Erişim Tarihi: 27.02.2017).

Baştürk, R. (2011). Deneme modelleri. (Editör: Abdurrahman Tanrı̈ğen), Bilimsel araştırma yöntemleri içinde (s.29-54), (2. Baskı). Ankara: Anı Yayıncilık.

Berrak, A. \& Hiperlink (Firm). (2007). Pınardaki geyik ile aslan. Yayına Hazırlayan: Aslı Berrak. Ezop Masalları, içinde. (s.28), MEB Tavsiyeli 100 temel eser ilköğretim 1. Kademe dizisi. İstanbul: Parıltı Yayıncılık. (Vol.1.bs). İstanbul: Hiperlink. Retrieved from Erişim adresi: <http://search.ebscohost.com/login.aspx?direct=true\&db=nlebk\&AN=595817\&lang=tr\&site=ehost-live> (Erişim Tarihi: 27.02.2017). 
Büyüköztürk, Ş. (2012). Sosyal bilimler için veri analizi el kitabı. Istatistik, araştırma deseni, SPSS uygulamaları ve yorum. (16. Baskı). Ankara: Pegem Akademi Yayıncılık.

Büyüköztürk, Ş., Kılıç Çakmak, E., Akgün, Ö. E., Karadeniz, Ş. \& Demirel, F. (2016). Bilimsel araştırma yöntemleri. (22. Baskı). Ankara: Pegem Akademi Yayıncılık.

Çelik, H. E. \& Yılmaz, V. (2013). LISREL 9.1 ile yapısal eşitlik modellemesi, temel kavramlar-uygulamalar-programlama. Ankara: Anı Yayıncılık.

İnceağaç, M. \& Yılmaz, M. (2018). Fabl türünün 7. sınıf öğrencilerinin görsel sanat çalışmalarına etkisi, Mehmet Akif Ersoy Üniversitesi Sosyal Bilimler Enstitüsü Dergisi, 10(24), 305-322. Erişim adresi: <http://dergipark.gov.tr/download/article-file/497701> (Erişim Tarihi:10.07.2018).

Internet, (2017). Zümrüdü Anka (Simurg) Kuşu Efsanesi, [Video]. Erişim adresi: <https://www.youtube.com/watch?v=bS21rqkmzyY> (Erişim Tarihi: 09.03.2017).

Kalaycı, Ş. (2009). SPSS uygulamalı çok değişkenli istatistik teknikleri. Ankara: Pegem Akademi Yayıncılık.

Kamer, Y. \& Hiperlink (Firm). (2011). Andersen'den masallar, Deniz kızı ve prens, içinde (s.3-16) MEB Talim Terbiye Kurulu başkanlığınca hazırlanan yeni okuma yazma programına uygun olarak hazırlanmıştır. Resimleyen: Yakup Kamer, B\&T (Birleşik Tomurcuk) Yayınları, Eflatun Matbaası İstanbul: Hiperlink. Retrieved from Erişim adresi: <http://search.ebscohost.com/login.aspx?direct=true\&db=nlebk\&AN=702291\&lang=tr\&site=ehost-live> (Erişim Tarihi: 09.03.2017).

Kavcar, C. (2017). Edebiyat ve Eğitim. (4. Baskı). Ankara: Anı Yayıncılık.

Kline, P. (1994). An easy guide to factor analysis. New York: Routledge.

Kline, R. B. (2011). Principles and practice of structural equation modeling. NY London: The Guilford.

Laçinbay, K. \& Yılmaz, M. (2015, Mayıs). Türk atasözlerinden yararlanarak, mizahın görsel sanatlar dersinde kullanımı. IV. Uluslararası Türk Sanatları, Tarihi ve Folkloru Kongresi/Sanat Etkinlikleri Kongresi'nde sunulmuş özet bildiri, Konya.

Malchiodi, C. A. (2005). Çocukların Resimlerini Anlamak (çev: Tülin Yurtbay) İstanbul: Epsilon Yayınevi.

Moskal, B. M., \& Leydens, J. A. (2000). Scoring rubric development: Validity and reliability. Practical Assessment, Reseach \& Evaluation, 7(10), 71-81.

Özkartal, M. (2009). Illköğretim sanat etkinlikleri dersinde Dede Korkut Destanı'nın milli değerlerin kazanılmasına etkisi. Yayımlanmamış Doktora Tezi, Gazi Üniversitesi Eğitim Bilimleri Enstitüsü, Ankara.

Şencan, H. (2005). Sosyal ve davranışsal ölçmelerde güvenirlik ve geçerlilik. Ankara: Seçkin Yayıncılık.

Tabachnick, B. G., \& Fidell, L. S. (1989). Using multivariale statistics. Cambridge: Harper \& Row.

Tavşancıl, E. (2006). Tutumların ölçülmesi ve SPSS ile veri analizi. Ankara: Nobel Akademik Yayıncılık.

Yılmaz, M. (2014). Görsel sanatlar eğitiminde mizahın yeri ve kaynakları. Akademik Bakış Dergisi, Uluslararası Hakemli Sosyal Bilimler E-Dergisi, iktisat ve Girişimcilik Üniversitesi Türk Sosyal Bilimler Enstitüsü, Celalabat-KIRGIZiSTAN, JEL KOD:120 ID:144 K:21, (40), Erişim adresi: <https://dergipark.org.tr/tr/download/article-file/382691> (Erişim Tarihi: 15.01.2017).

Yılmaz, M. \& İnceağaç, M. (2017). Görsel sanatlar eğitimi uygulamalarında edebiyat ürünlerinin etkisini belirlemeye yönelik dereceli puanlama anahtarının (rubrik) geliştirilmesi, Erzincan Üniversitesi Eğitim Fakültesi Dergisi, 19(3), 1-16. Erişim adresi: <http://dergipark.gov.tr/download/article-file/384856> (Erişim Tarihi: 15.02.2018).

Yılmaz, O. (2015). Kurbağa ile Kazlar. Hazırlayan: Ozan Yılmaz. (Editör: Cumhur Ün). Beydeba Kelile ve Dimne'den Seçmeler, içinde (s.52-54), Hasbahçe kitaplığı/18, İstanbul: Çamlıca Basım Yayın. T.C. Kültür Bakanlığı Yayıncılık Sertifika No: 15732

\section{EK. ÖĞRENCI RESIMLERi}

Öğrenci No: 1

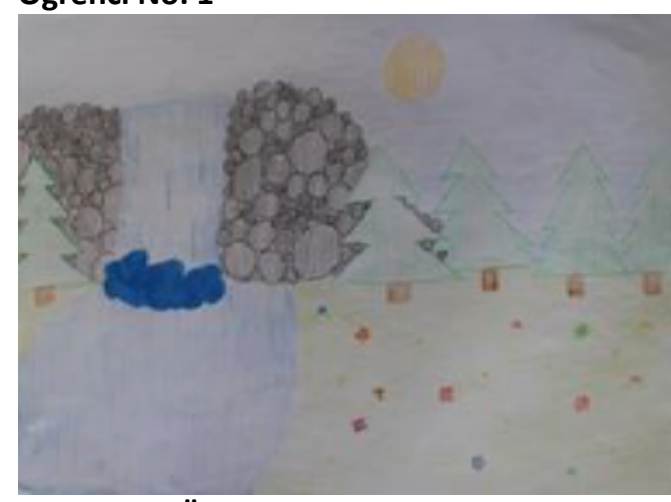

Resim No 1: Öntest "Serbest Çalışma”

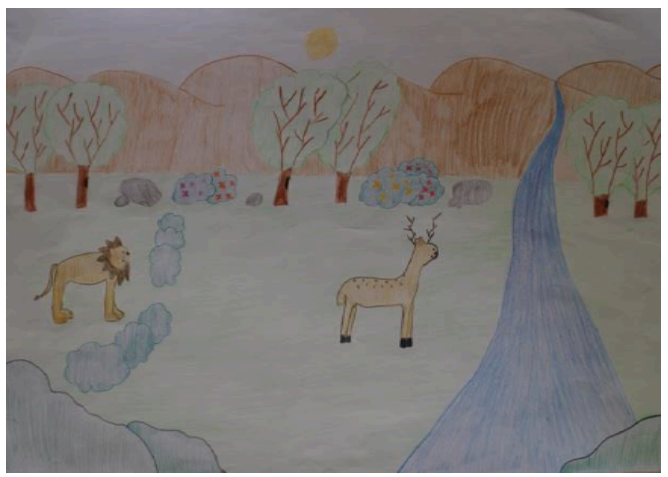

Resim No 2: Sontest 1 "Fabllara Ait Uygulama” 


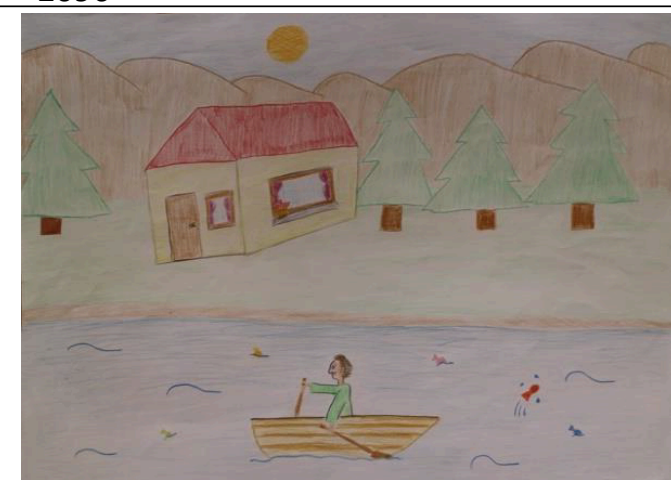

Resim No 3: Sontest 2 “Atasözleri-Deyimlere Ait Uygulama”

\section{Öğrenci No: 2}

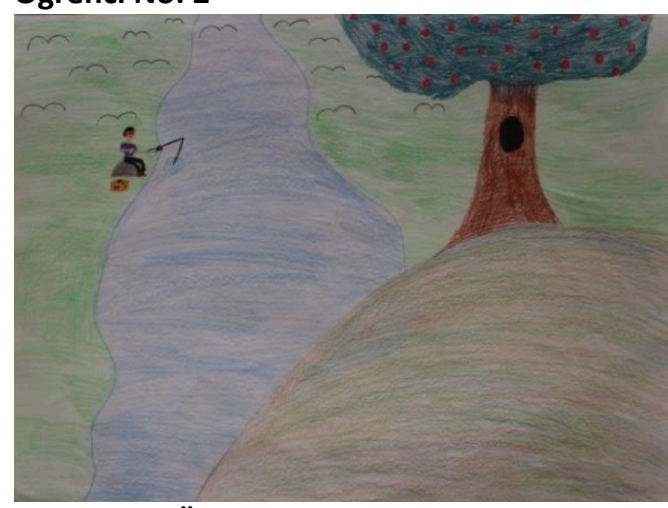

Resim No 5: Öntest "Serbest Çalışma"

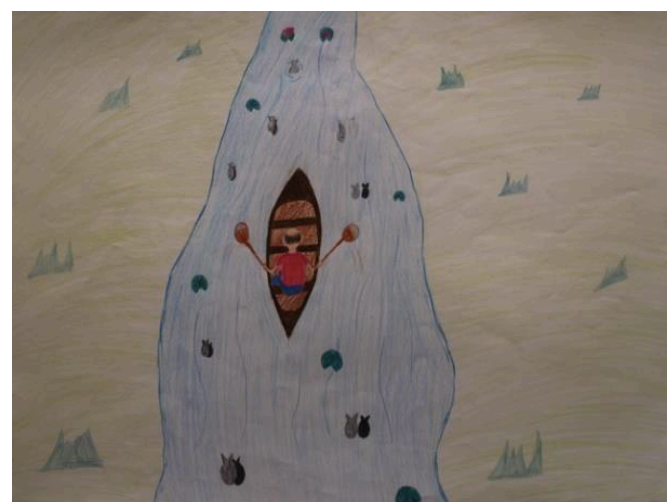

Resim No 7: Sontest 2 "Atasözleri-Deyimlere Ait Uygulama”

\section{Öğrenci No: 3}

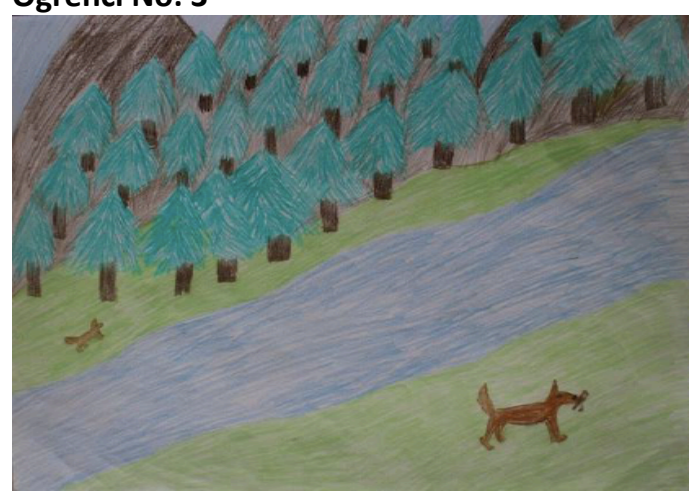

Resim No 9: Öntest “Serbest Çalışma”

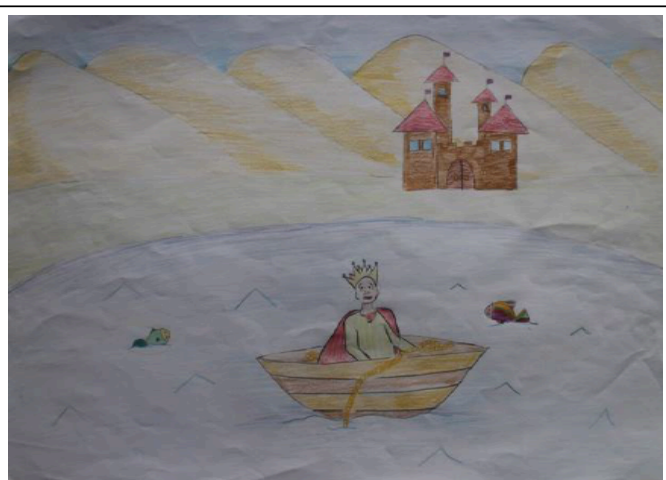

Resim No 4: Sontest 3 "Efsanelere Ait Uygulama”

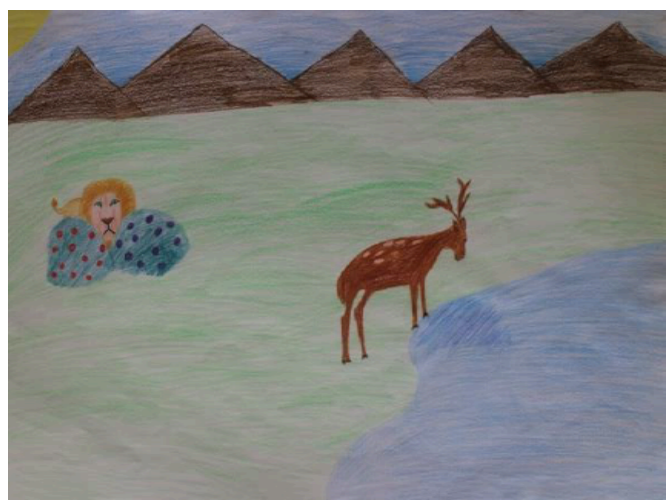

Resim No 6: Sontest 1 "Fabllara Ait Uygulama”

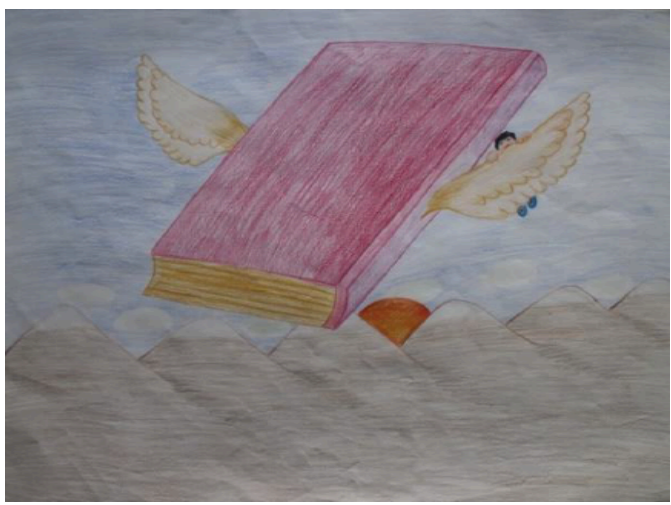

Resim No 8: Sontest 3 “Efsanelere Ait Uygulama”

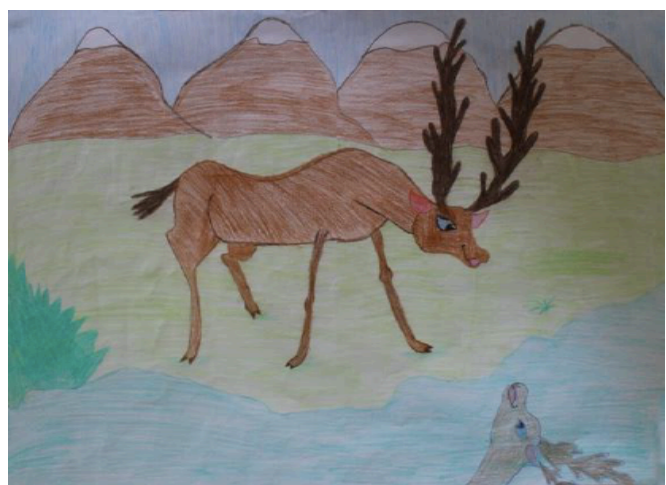

Resim No 10: Sontest 1 "Fabllara Ait Uygulama” 


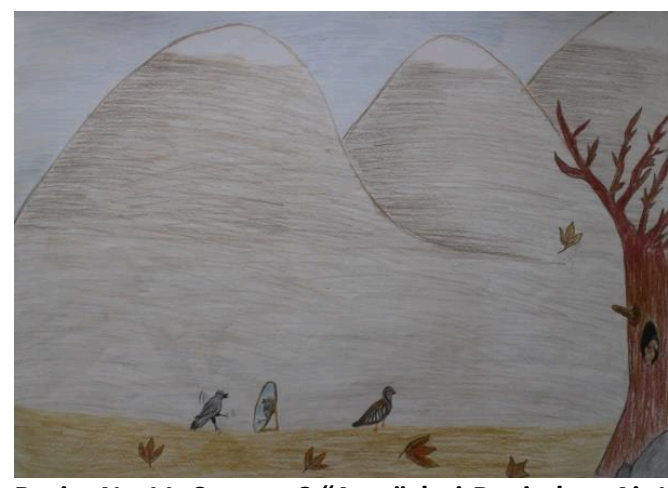

Resim No 11: Sontest 2 “Atasözleri-Deyimlere Ait Uygulama”

\section{Öğrenci No: 4}

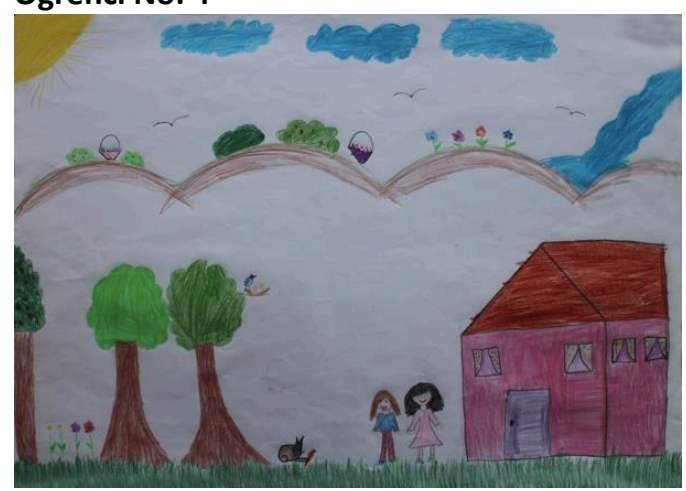

Resim No 13: Öntest “Serbest Çalışma”

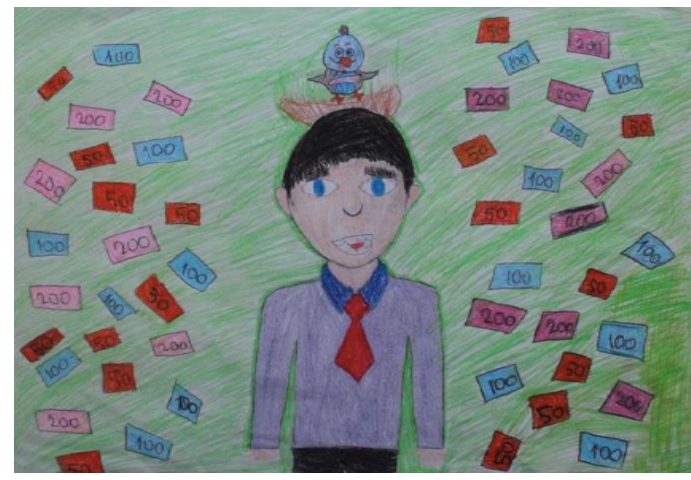

Resim No 15: Sontest 2 "Atasözleri-Deyimlere Ait Uygulama”

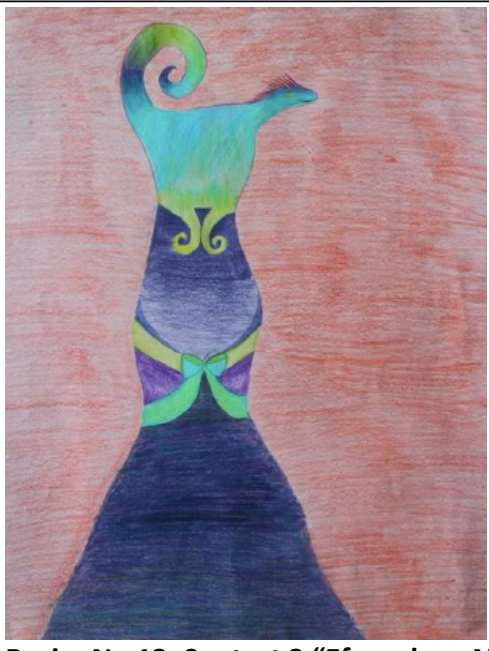

Resim No 12: Sontest 3 "Efsanelere Ait Uygulama”

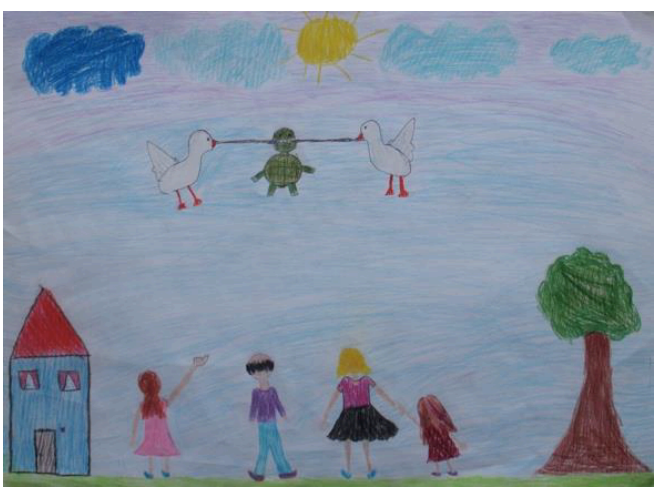

Resim No 14: Sontest 1 “Fabllara Ait Uygulama”

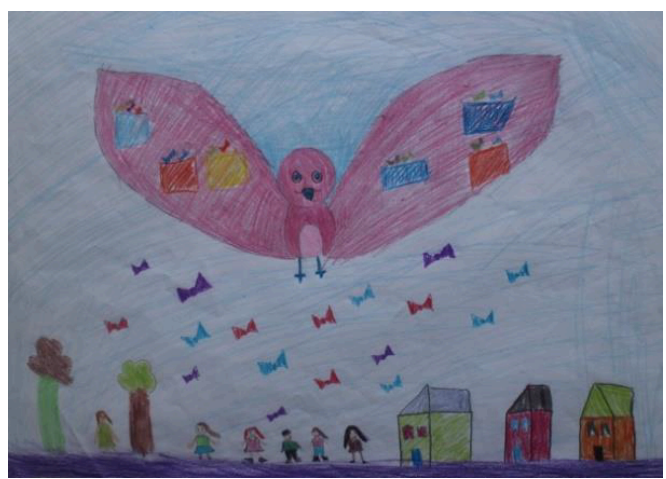

Resim No 16: Sontest 3 "Efsanelere Ait Uygulama” 


\section{Öğrenci No: 5}

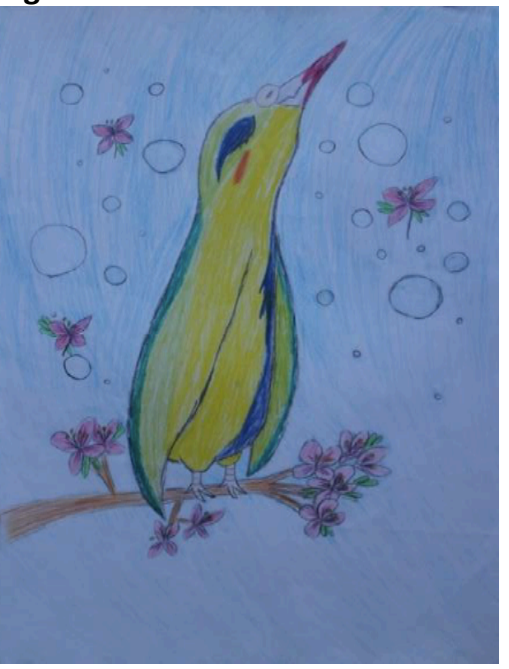

\section{Resim No 17: Öntest “Serbest Çalışma”}

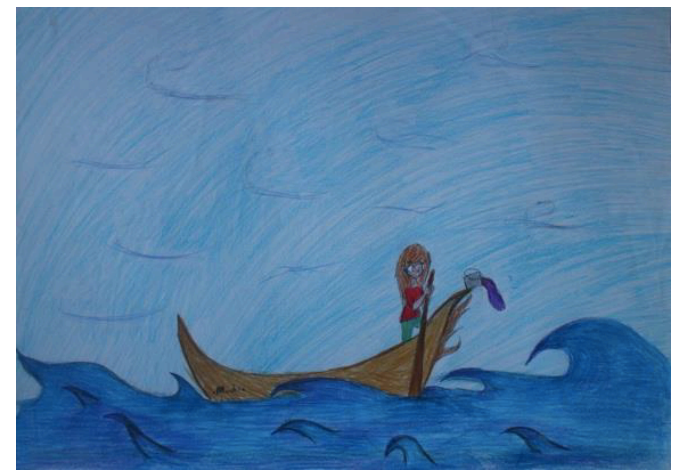

Resim No 19: Sontest 2 “Atasözleri-Deyimlere Ait Uygulama”

\section{Öğrenci No: 6}

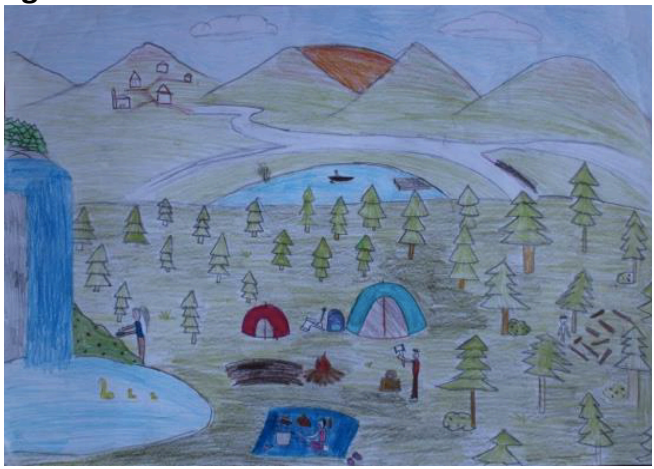

Resim No 21: Öntest "Serbest Çalışma"

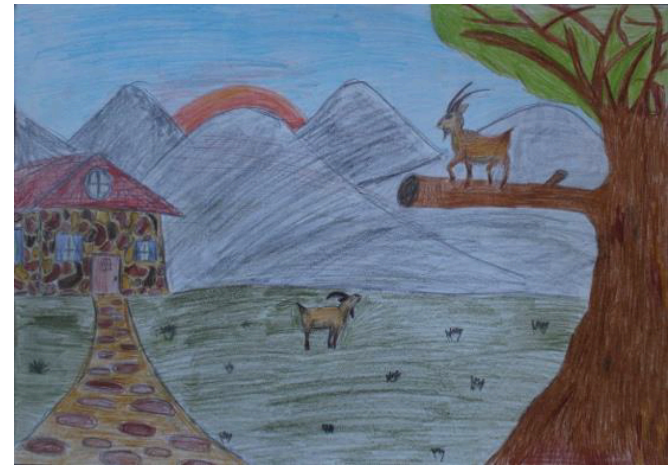

Resim No 23: Sontest 2 “Atasözleri-Deyimlere Ait Uygulama”

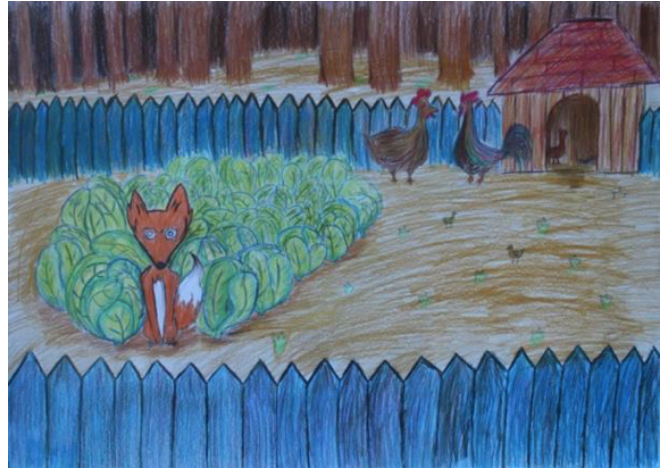

Resim No 18: Sontest 1 "Fabllara Ait Uygulama”

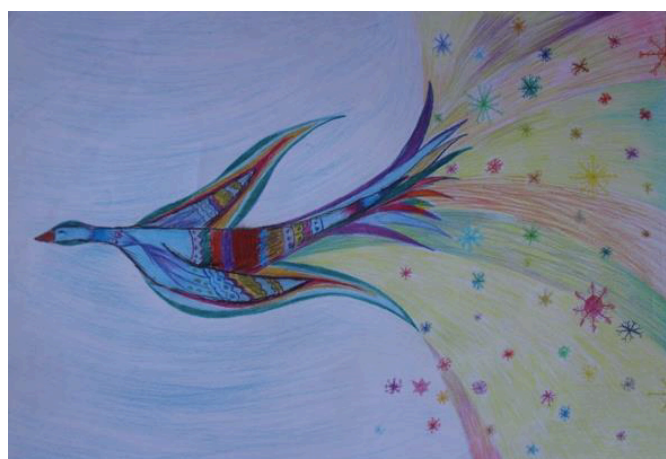

Resim No 20: Sontest 3 "Efsanelere Ait Uygulama”

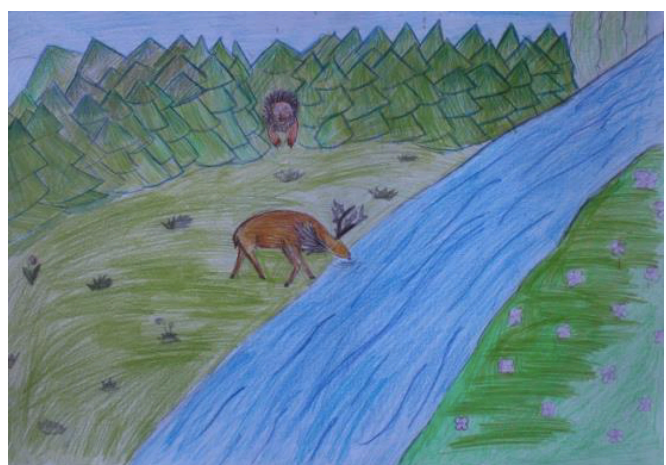

Resim No 22: Sontest 1 “Fabllara Ait Uygulama”

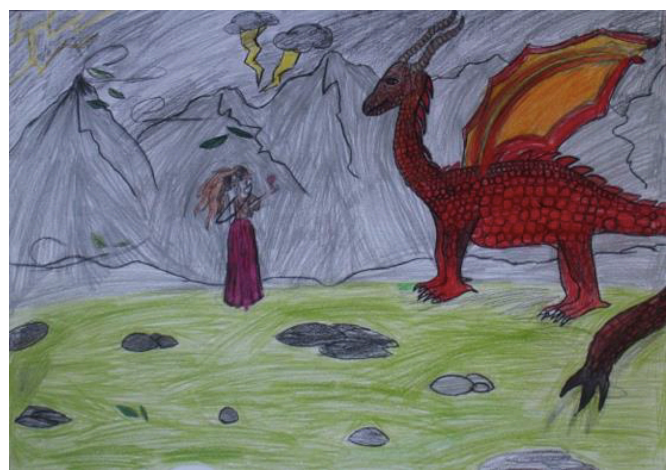

Resim No 24: Sontest 3 "Efsanelere Ait Uygulama” 


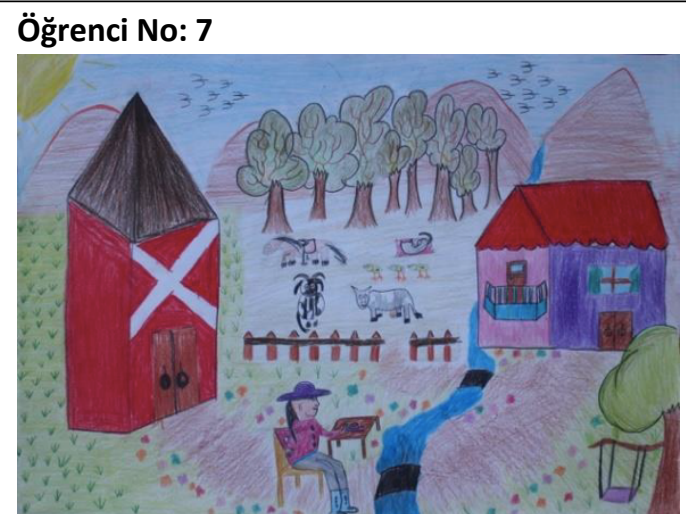

Resim No 25: Öntest “Serbest Çalışma”

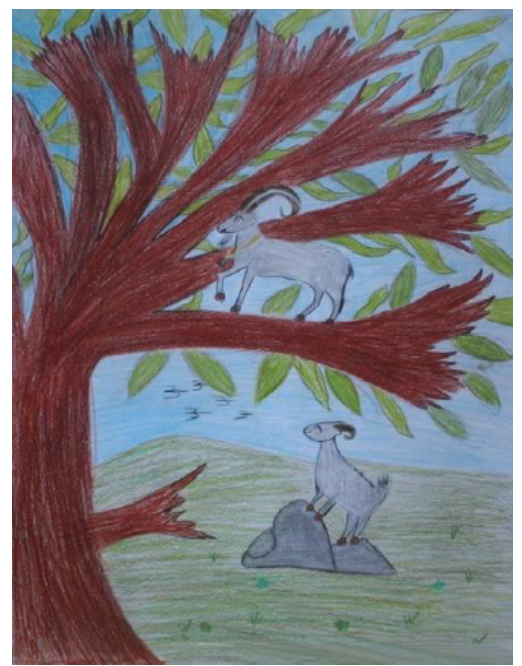

Resim No 27: Sontest 2 “Atasözleri-Deyimlere Ait Uygulama”

\section{Öğrenci No: 8}

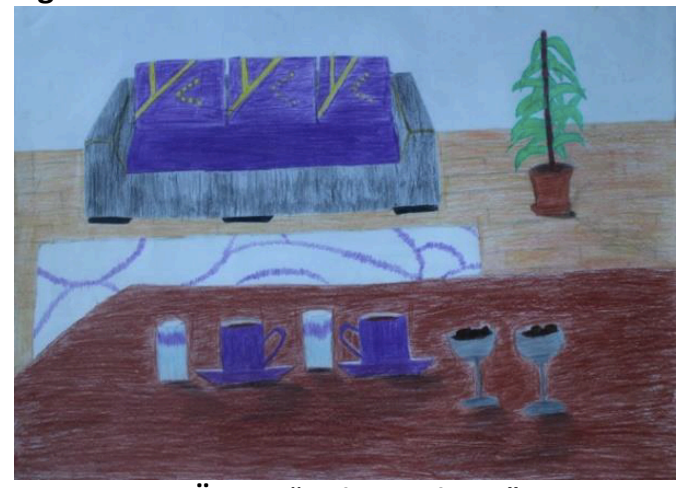

Resim No 29: Öntest “Serbest Çalışma”

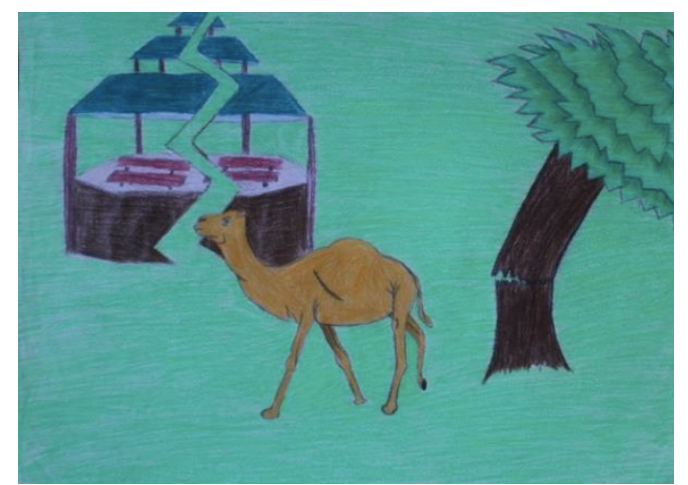

Resim No 31: Sontest 2 “Atasözleri-Deyimlere Ait Uygulama”

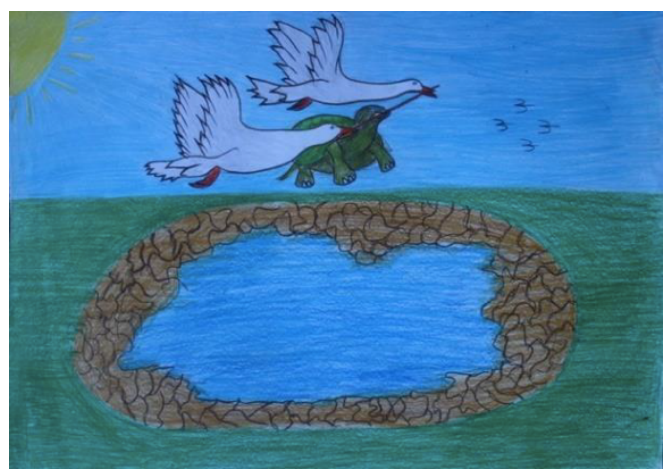

Resim No 26: Sontest 1 "Fabllara Ait Uygulama”

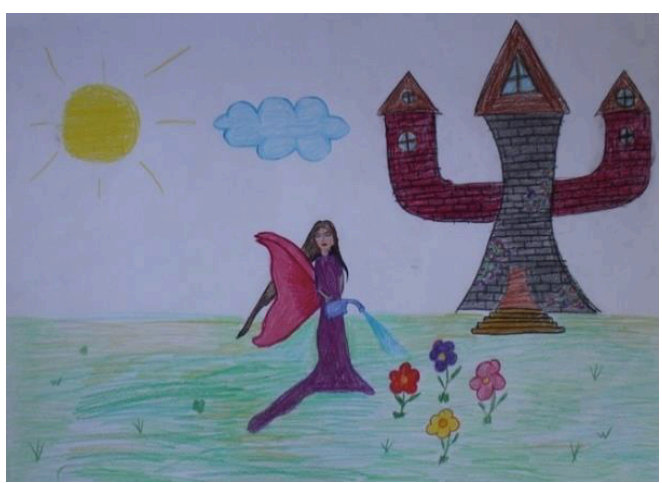

Resim No 28: Sontest 3 "Efsanelere Ait Uygulama”

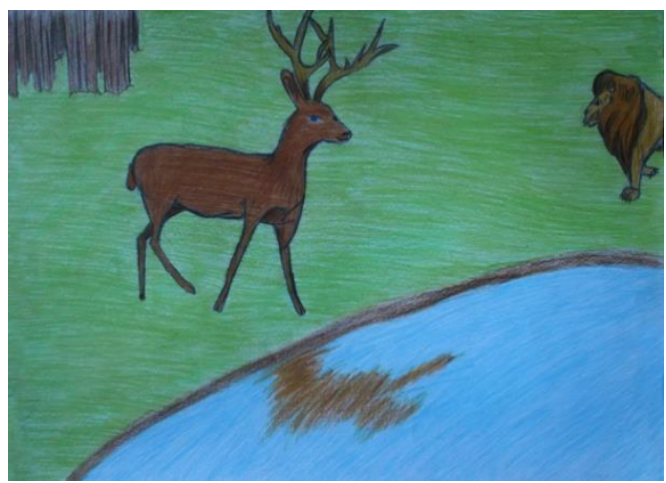

Resim No 30: Sontest 1 "Fabllara Ait Uygulama”

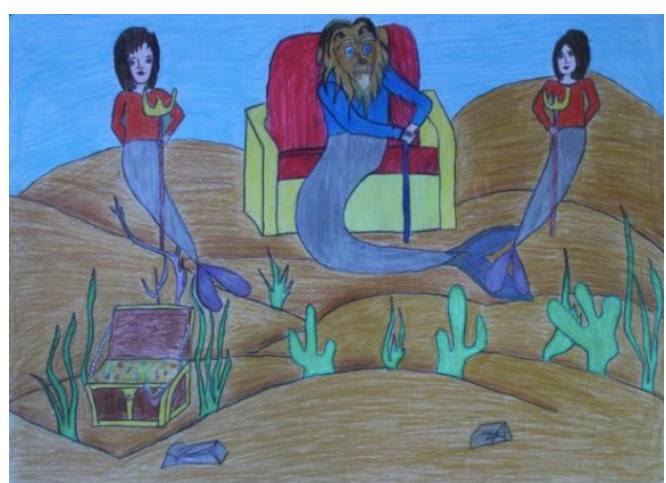

Resim No 32: Sontest 3 “Efsanelere Ait Uygulama” 